\title{
Proportionality as a ReMedial Principle: A FRAMEWORK FOR SUSPENDED DECLARATIONS OF INVALIDITY IN CANADIAN CONSTITUTIONAL LAW
}

\author{
GRANT R HOOLE*
}

The aim of this article is to provide an analytic framework for the governance of suspended declarations of invalidity in Canadian constitutional law. A suspended declaration is a remedial device by which a court strikes down a constitutionally invalid law, but suspends the effect of its order such that the law retains force for a temporary period. While introduced to Canadian law under circumstances of exigency, suspended declarations have grown to be used liberally by the courts, and the principles that previously confined them have been abandoned. As a result, constitutional rights — including those protected in the Charter of Rights and Freedoms have sometimes been suspended without just basis. I propose a means to reverse this trend: by adopting proportionality, a core feature of the analytic method used to adjudicate limitations on Charter rights, as a remedial principle guiding the use of suspended declarations. Proportionality analysis is capable of navigating the features of remedial discretion engaged by suspended declarations, while reconciling the latter with Canada's constitutional principles.
Le but de cet article est de fournir un cadre analytique de gouvernance pour les déclarations d'invalidité suspendues dans le droit constitutionnel canadien. Une déclaration suspendue est un mécanisme correctif qui permet à la cour d'abolir une loi constitutionnelle invalide, mais suspend l'effet de son ordonnance de sorte que la loi demeure en vigueur pendant un certain temps. Introduites dans le droit canadien dans des circonstances d'urgence, les déclarations suspendues sont de plus en plus employées de manière libérale par les tribunaux, et les principes qui auparavant les confinaient ont été abandonnés. Par conséquent, les lois constitutionnelles - incluant celles qui sont protégées par la Charte des droits et libertés - ont parfois été suspendues sans motif valable. Je propose un moyen de renverser cette tendance en adoptant la proportionnalité, un élément fondamental de la méthode analytique utilisée pour trancher les limites des droits de la Charte, en tant que principe correctif pour le recours aux déclarations suspendues. L'analyse de la proportionnalité est en mesure de naviguer dans la discrétion corrective motivant les déclarations suspendues tout en les rapprochant des principes constitutionnels du Canada.

\section{TABLE OF CONTENTS}

I. InTRODUCTION AND OVERVIEW . . . . . . . . . . . . . . . . . . 108

II. ORIGINS, EVOLUTION, AND PROBLEMS ARISING FROM

SUSPENDED DECLARATIONS OF INVALIDITY $\ldots \ldots \ldots \ldots \ldots \ldots \ldots \ldots$

A. Definition and Early Case LaW . . . . . . . . . . . . 110

B. THE EXPANDED USE OF SUSPENDED

DECLARATIONS OF INVALIDITY . . . . . . . . . . . . . . . . . . . . . . . . . 114

C. The Problem of InAdeQuate ReAsoning $\ldots \ldots \ldots \ldots \ldots \ldots \ldots$

D. The PRoblem of Flawed

InSTITUTIONAL AsSUMPTIONS . . . . . . . . . . . . . . . . . . . 123

E. The Problem of InJuRy to CHARTER RightS . . . . . . . . . . . . 128

F. SUSPENDED DECLARATIONS AND THE Dilemmas

OF REMEDIAL DISCRETION . . . . . . . . . . . . . . . . . . . . . 131

BA(Hons), LLB, BCL, LLM, member of the Bar of Ontario. I would like to thank Kent Roach, Lorraine Weinrib, and two anonymous peer reviewers for their thoughtful feedback on earlier versions of this article. I am also grateful for the excellent editorial assistance of the staff of the Alberta Law Review. Errors and omissions are my own. 
III. PROPORTIONALITY AND THE LiMitATION

OF CHARTER RIGHTS . . . . . . . . . . . . . . . . . . . . . . . . . . 136

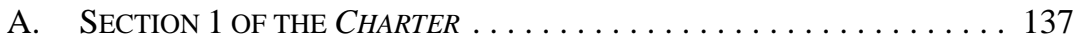

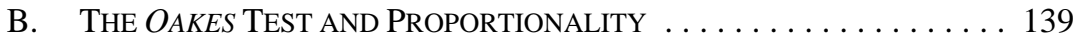

C. PROPORTIONALITY ANALYSIS AND SUSPENDED

DECLARATIONS OF INVALIDITY . . . . . . . . . . . . . . . . . . . 144

IV. CONCLUSION .......................... 147

\section{INTRODUCTION AND OVERVIEW}

Suspended declarations of invalidity have become a familiar feature of Canadian constitutional jurisprudence. Having originated as an exceptional remedy, enabling courts to temporarily suspend the effect of a declaration invalidating a law on constitutional grounds, a suspended declaration is now included in the majority of Supreme Court of Canada decisions in which the power of statutory invalidation is utilized. As the usage of suspended declarations has grown, the justifications for their use have evolved. No longer are they reserved for instances of "emergency," in which the invalidation of an unconstitutional law would result in imminent danger to the public. Rather, suspended declarations are now used to instantiate a particular conception of the proper roles of legislatures and courts. In that conception the courts primarily serve a declarative function, pronouncing instances in which statutes or regulations deviate from constitutional requirements. The work of devising a precise remedial solution is left to the legislatures.

The prominent, evolved usage of suspended declarations of invalidity has serious implications for Canadian constitutional law. For one thing, suspended declarations engage real consequences for individual litigants and others affected by judicial decisions, as laws found to violate the Constitution are permitted to have a continued, temporary effect. Moreover, on a systemic level, suspended declarations reinforce an operational separation of powers premised on institutional assumptions that are subject to criticism and debate.

My aim in this article is to critique the dominant mode in which suspended declarations of invalidity are used by Canada's courts and to propose an analytic framework that would render their use less damaging to the rights of individuals and more consistent with Canada's constitutional principles.

I begin by documenting the origins of suspended declarations of invalidity, emphasizing the principled basis on which they were introduced to Canadian law. I then demonstrate how the recent proliferation of suspended declarations deviates from those principles and produces a series of interrelated problems - a problem of inadequate judicial reasoning, a problem of flawed institutional assumptions, and a problem of injury to Charter rights. I attempt to explain how these problems arose and why the original authorities on suspended declarations have come to be neglected by the courts. This discussion establishes the need for a revised analytic framework governing the issuance of suspended declarations: one that reinforces commitment to the values of Canada's Constitution, but accommodates remedial challenges that may have been unforeseen at the time the original cases on suspended declarations were decided. 
The remainder of my article is devoted to developing such a framework. It rests upon an analogy between suspended declarations of invalidity and the limitation of rights by legislative action. From the perspective of a rights-holding individual, the effects of a declaration temporarily extending the operation of an unconstitutional law will often be equivalent to the outright limitation of a right. Canada's Constitution includes a framework for the limitation of rights recognized in the Canadian Charter of Rights and Freedoms. ${ }^{1}$ The essence of this framework is that rights may only be limited in the fulfillment of constitutionally legitimate objectives, narrowly tailored pursuant to a doctrine of proportionality. Constitutional integrity is thus preserved in the face of limiting rights, as both rights and their limitations are justified by common constitutional values. This framework is derived from a "postwar" model of rights protection, reflected in the constitutional jurisprudence of many countries and formally adopted in Canada with the entrenchment of the Charter. Suspended declarations of invalidity find their governing principles in the same source. Hence, the analytical devices employed to verify the legitimate limitation of Charter rights are useful in defining a constitutional role for suspended declarations of invalidity. I thus advocate the adoption of proportionality as a remedial principle governing the issuance of suspended declarations. This would require that when courts choose to issue a suspended declaration, they demand of themselves the same standards that they demand of a government seeking to justify the limitation of a right, namely: that a suspended declaration serve a pressing and substantial objective; that it be rationally connected to that objective; that it be minimally impairing of the constitutional rights it affects; and that the harsh consequences of suspension be proportionate to the constitutional benefit obtained.

The use of proportionality as such a remedial principle involves a rereading of the foundational cases that gave rise to suspended declarations, notably the Supreme Court's decisions in Reference Re Manitoba Language Rights, ${ }^{2} R v$ Swain, ${ }^{3}$ and Schachter $v$ Canada. ${ }^{4}$ It focuses attention on the animating principles of those cases and provides an intelligible standard by which the principles may be applied in novel circumstances, rather than confining courts to restrictive "categories" in which suspended declarations may be applied pursuant to the examples of earlier decisions. It is also responsive to the unique dilemmas confronted by courts in exercising their remedial discretion.

The promotion of proportionality as a remedial principle is not intended to eliminate suspended declarations of invalidity from Canadian jurisprudence. Proportionality does, however, command a rigorous analytic approach that requires any limitation (or, in this case, suspension) of constitutional rights to be consistent with the principles of a free and democratic society. It maintains the primacy of constitutionalism in the face of impingements on rights. The use of proportionality to guide judicial discretion regarding suspended declarations will thus necessarily result in a more circumspect role for the latter. That role is entirely consistent, however, with the commitments of Canada's constitutional structure,

Part I of the Constitution Act, 1982, being Schedule B to the Canada Act 1982 (UK), 1982, c 11 [Charter].

[1985] 1 SCR 721 [Manitoba Language Reference].

[1991] 1 SCR 933 [Swain].

[1992] 2 SCR 679 [Schachter]. 
as it concerns both the protection of individual rights and the institutional roles of legislatures and courts.

\section{Origins, Evolution, AND Problems Arising From SUSPENDED DECLARATIONS OF INVALIDITY}

This section explains the nature of suspended declarations of invalidity and describes their evolution from an exceptional remedy to a routine feature of constitutional adjudication. The result of this evolution is that suspended declarations are no longer moored to their original, governing principles. I attempt to explain why this has occurred and to demonstrate the adverse implications for individual rights and for the sanctity of constitutional principles.

\section{A. Definition AND EARLy CaSe LAW}

A suspended declaration occurs when courts choose to delay the effect of invalidating a law. A court may declare a law to be invalid, but "suspend" the effect of the declaration until a future date. During the interim period, the law continues to apply. At the expiry of the period, the court's declaration takes full effect: unless the law has been replaced or amended to comply with the Constitution, it is rendered null. ${ }^{5}$

Canada's constitutional text makes no provision for suspended declarations of invalidity. Section 52 of the Constitution Act, 1982 simply affirms the supremacy of the Constitution relative to ordinary statutes: "The Constitution of Canada is the supreme law of Canada, and any law that is inconsistent with the provisions of the Constitution is, to the extent of the inconsistency, of no force or effect." ${ }^{6}$ On a plain reading of this provision, the invalidation of any law found to be ultra vires the Constitution should be immediate. This was the exclusive approach of the courts prior to the introduction of suspended declarations of invalidity to Canadian law by the Supreme Court in 1985. The latter point is worth emphasizing: many judicial decisions of profound consequence in Canada's legal history such as the invalidation of legal restrictions on abortion, ${ }^{7}$ the elimination of barriers against the public dissemination of controversial religious views, ${ }^{8}$ the invalidation of a law enforcing a religiously-grounded day of rest, ${ }^{9}$ and the invalidation of evidentiary and procedural barriers to the defence of the criminally accused ${ }^{10}$ — were given immediate effect, allowing no grace period for either the legislatures or the public to "adjust.” Many of those decisions, although controversial at the time, are regarded now as hallmarks in the development of a fair and tolerant society. Unlike case law from earlier periods of Canada's constitutional development, however, immediate declarations of invalidity are no longer the norm. Suspended declarations have emerged as the remedial instrument of choice in most cases

See generally Kent Roach, Constitutional Remedies in Canada (Aurora: Canada Law Book, 1994) at paras 14.1480ff [Roach, Constitutional Remedies].

Being Schedule B to the Canada Act 1982 (UK), 1982, с 11, s 52.

$R v$ Morgentaler, [1988] 1 SCR 30 [Morgentaler].

Saumur v Quebec (City of), [1953] 2 SCR 299 [Saumur].

$R v$ Big M Drug Mart, [1985] 1 SCR 295 [Big M].

See e.g. $R v$ Oakes, [1986] 1 SCR 103 [Oakes], striking down a reverse onus provision of the Criminal Code, RSC 1985, c C-46, that created a presumption of trafficking upon possession of a certain quantity of narcotics, and overturning the conviction of the accused. 
involving the invalidation of unconstitutional laws, at least in the jurisprudence of the Supreme Court of Canada.

\section{The MANITOBA LANGUAGE REFERENCE AND EARLy USES OF SUSPENDED DECLARATIONS}

The origins of suspended declarations lie in the Supreme Court's 1985 decision in the Manitoba Language Reference. Upon finding that the Legislative Assembly of Manitoba had, for 95 years, ignored the constitutional requirement of the Manitoba Act, $1870^{11}$ that all provincial statutes be enacted in both official languages, the Court feared that an immediate declaration of invalidity would plunge the province into a state of lawlessness. Indeed, the immediate nullification of the offending statutes would not simply have denied effect to virtually all provincial laws, but would have undermined every state action, agency, public, and private right constituted under those laws that could not otherwise be saved by the de facto doctrine or by res judicata. ${ }^{12}$ The result would have been a "legal vacuum" inimical to the very rule of law. ${ }^{13}$ The Court accordingly fashioned a unique remedy. It held:

\footnotetext{
The Constitution will not suffer a province without laws. Thus the Constitution requires that temporary validity and force and effect be given to the current Acts of the Manitoba Legislature from the date of this judgment, and that rights, obligations and other effects which have arisen under these laws and the repealed and spent laws of the Province prior to the date of this judgment, which are not saved by the de facto or some other doctrine, are deemed temporarily to have been and continue to be effective and beyond challenge. It is only in this way that legal chaos can be avoided and the rule of law preserved. ${ }^{14}$
}

Suspended declarations of invalidity were thus introduced to Canadian law for the purpose of averting a constitutional crisis. Recognizing the extremity of this remedial measure, the Court emphasized both the "emergency"15 circumstances that necessitated it, and circumscribed the duration of the suspended declaration to only the "minimum period necessary” ${ }^{\text {16 }}$ for the legislature to correct the constitutional defect.

The usage of suspended declarations by Canada's courts grew incrementally during the decade following the Manitoba Language Reference. For the most part, ${ }^{17}$ suspended declarations of invalidity were utilized to avert a harm that would be consequent upon the immediate invalidation of a law, consistent with the Manitoba Language Reference. Thus, in Dixon v British Columbia (AG), ${ }^{18}$ the British Columbia Supreme Court invalidated a system of provincial electoral boundaries found to violate the Charter right to vote, but suspended its declaration so that a functional electoral system would remain in place in the event of an election. The possibility that, in a system of parliamentary democracy, an election could be called at any time was found to constitute an "emergency" justifying a suspended

33 Vict, c 3 (Canada), reprinted in RSC 1985, App II.

Manitoba Language Reference, supra note 2 at 747-48, 767.

Ibid at 747.

Ibid at 767.

Ibid at 763 .

Ibid at 767 .

The use of suspended declarations during this period is well-documented elsewhere, and given only a summary treatment here. For a more detailed treatment, see Roach, Constitutional Remedies, supra note 5 at paras 14.1480-14.1790. 
declaration in line with the Manitoba Language Reference. ${ }^{19}$ In Swain, the Supreme Court of Canada issued a six-month suspension of its declaration that the then section 542(2) of the Criminal Code, which provided for the automatic detention of persons acquitted of criminal charges on the ground of insanity, violated sections 7 and 9 of the Charter. The Court reasoned that an immediate declaration of invalidity could result in potentially dangerous individuals being released into the public, and as such, the suspended declaration was required to preserve public safety while Parliament crafted a more nuanced provision. ${ }^{20}$ Importantly, during the period of suspension, the Court imposed an interim regime limiting the detention of individuals to 30 days, subject to habeas corpus review by a judge of the Superior Court.

\section{INTRODUCTION OF THE SCHACHTER GUIDELINES}

The Supreme Court's next major application of a suspended declaration of invalidity arose in Schachter. Schachter concerned a challenge under section 15 of the Charter to the federal government's regime of parental benefits. The regime provided equal benefits to adoptive parents and to biological mothers, but not to biological fathers. The Court found that biological fathers were discriminated against by their exclusion from the regime, in contravention of section 15 of the Charter. Nevertheless, having found that the impugned provisions could not simply be severed from the legislation or corrected by reading in, the Court wished to avoid the denial of parental benefits to existing recipients, which would have resulted from the immediate invalidation of the law. The Court accordingly opted to issue a suspended declaration, reasoning that this measure was justified when "striking down the law immediately would deprive deserving persons of benefits without providing them to the applicant.”21 Writing for the majority of the Court, Chief Justice Lamer went on to introduce guidelines for the appropriate use of suspended declarations, drawing the Court's earlier decisions in the Manitoba Language Reference and Swain:

Temporarily suspending the declaration of invalidity to give Parliament or the provincial legislature in question an opportunity to bring the impugned legislation or legislative provision into line with its constitutional obligations will be warranted ... [when]:

A. striking down the legislation without enacting something in its place would pose a danger to the public;

B. striking down the legislation without enacting something in its place would threaten the rule of law; or,

C. the legislation was deemed unconstitutional because of underinclusiveness rather than overbreadth, and therefore striking down the legislation would result in the deprivation of benefits from deserving persons without thereby benefitting the individual whose rights have been violated. ${ }^{22}$

Ibid at 282-83.

Supra note 3 at 1021-22.

Supra note 4 at 715-16.

Ibid at 719 . 
Although these guidelines were not intended to be "hard and fast rules," 23 the Court nevertheless stressed that suspended declarations were to remain an exceptional remedy. Chief Justice Lamer's reasons warrant quotation at length:

While delayed declarations are appropriate in some cases, they are not a panacea for the problem of interference with the legislature under s. 52.

A delayed declaration is a serious matter from the point of view of enforcement of the Charter. A delayed declaration allows a state of affairs which has been found to violate standards embodied in the Charter to persist for a time despite the violation. There may be good pragmatic reasons to allow this in particular cases. However, reading in is much preferable where it is appropriate, since it immediately reconciles the legislation in question with the requirements of the Charter.

Furthermore, the fact that the court's declaration is delayed is not really relevant to the question of which course of action, reading in or nullification, is less intrusive upon the institution of the legislature. By deciding upon nullification or reading in, the court has already chosen the less intrusive path. If reading in is less intrusive than nullification in a particular case, then there is no reason to think that delayed nullification would be any better. To delay nullification forces the matter back onto the legislative agenda at a time not of the choosing of the legislature, and within time limits under which the legislature would not normally be forced to act. This is a serious interference in itself with the institution of the legislature. Where reading in is appropriate, the legislature may consider the issue in its own good time and take whatever action it wishes. Thus delayed declarations of nullity should not be seen as preferable to reading in in cases where reading in is appropriate.

The question whether to delay the application of a declaration of nullity should therefore turn not on considerations of the role of the courts and the legislature, but rather on considerations listed earlier relating to the effect of an immediate declaration on the public. ${ }^{24}$

The Court's circumscription of suspended declarations thus stemmed both from concern for the protection of Charter rights, and from a particular understanding of the jurisdictional role of courts. Regarding the latter, the Court observed that the decision to strike down a legislative provision is taken once a court has established that a constitutional defect cannot be cured by alternate means, such as reading in, severance, or reading down, without disrupting the intent of the legislature and thus overstepping the jurisdiction of the court. Having completed this inquiry, the decision as to whether a declaration of invalidity is to be immediate or suspended should, in the Court's view, focus entirely on the interests of the public. Implicit in this reasoning is a delineation of the court's jurisdictional role: the court is bound to respect the law-making prerogative of legislatures in selecting among remedial options, but this consideration terminates once a specific remedy, such as striking down, has been chosen. This is because the court will have already determined that striking down is "the least intrusive path" vis-à-vis the legislature's jurisdiction. Further consideration of the court's proper institutional role should not bear on the decision to issue a suspended declaration, because this consideration is addressed in the initial choice of remedy. 
It is this aspect of the Court's ruling in Schachter with which the subsequent case law is most at odds, despite the absence of any decision expressly overruling Schachter. As the discussion of cases below will make clear, the courts have tended to disregard the Schachter guidelines, instead justifying suspended declarations in reference to institutional considerations that fly in the face of Chief Justice Lamer's cautioning remarks.

\section{B. THE EXPANDED USE OF SUSPENDED DECLARATIONS OF INVALIDITY}

The Charter fundamentally transformed the exercise of legislative power in Canada. The limits of that power were no longer derived simply from the jurisdictional purview of the respective levels of government, but from the sanctity of inherent rights attaching to individuals. Despite this transformation, however, during the first four years in which the Charter took effect - a period that saw momentous decisions such as Hunter $v$ Southam, ${ }^{25}$ $R v$ Big M Drug Mart, $R$ v Oakes, and $R v$ Morgentaler - the Supreme Court of Canada did not issue a single suspended declaration in a Charter case.

Bruce Ryder has documented the growing use of suspended declarations since that time. ${ }^{26}$ From 1989-93 (a period that included Swain and Schachter) the Supreme Court issued a suspended declaration in three out of 22 Charter cases involving the nullification of an unconstitutional law. ${ }^{27}$ From 1994-98, suspended declarations were issued in two out of 12 such cases (17 percent). ${ }^{28}$ It was during the period of 1998 to 2003 that things took a major turn, with the Supreme Court issuing a suspended declaration in eight of 14 nullification cases (57 percent). ${ }^{29}$ This trend has not abated. Since the publication of Ryder's article in 2003, the Supreme Court has invoked the Charter to nullify legislation in at least 11 cases, ${ }^{30}$ eight of which (73 percent) included the issuance of a suspended declaration. ${ }^{31}$

\section{$25 \quad$ [1984] 2 SCR 145.}

$26 \quad$ See Bruce Ryder, “Suspending the Charter” (2003) 21 SCLR (2d) 267.

Ibid at 273, 290-91.

Ibid.

Ibid at 273, 292-93.

Trociuk v British Columbia (AG), 2003 SCC 34, [2003] 1 SCR 835; Figueroa v Canada (AG), 2003 SCC 37, [2003] 1 SCR 912 [Figueroa]; Nova Scotia (Workers’ Compensation Board) v Martin, 2003 SCC 54, [2003] 2 SCR 504; Chaoulli v Quebec (AG), 2005 SCC 35, [2005] 1 SCR 791 [Chaoulli] (striking down legislation under the Quebec Charter of Human Rights and Freedoms, RSQ, c C-12, with three of the four majority justices finding the offending provision to also violate the Charter); $R v$ Demers, 2004 SCC 46, [2004] 2 SCR 489 [Demers]; Charkaoui v Canada (Citizenship and Immigration), 2007 SCC 9, [2007] 1 SCR 350 [Charkaoui]; Canada (AG) v Hislop, 2007 SCC 10, [2007] 1 SCR 429; Health Services and Support -Facilities Subsector Bargaining Association v British Columbia, 2007 SCC 27, [2007] 2 SCR 391 [Health Services]; $R v$ DB, 2008 SCC 25, [2008] 2 SCR 3; Nguyen v Quebec (Education, Recreation and Sports), 2009 SCC 47, [2009] 3 SCR 208 [Nguyen]; Greater Vancouver Transport Authority v Canadian Federation of Students - British Columbia Component, 2009 SCC 31, [2009] 2 SCR 295. Two of these cases, Trociuk and Figueroa, were decided in 2003 and included in Ryder's statistics for the 1998-2003 period. Ryder does not give extensive treatment to Figueroa, however, the latter having been decided shortly before publication of his article. Were Trociuk and Figueroa to be removed from my set of cases for the 2003-2010 period, the incidence of suspended declarations would be six out of nine, or 67 percent. The remaining cases were identified by my own electronic database searches of Supreme Court decisions between 2003 and 2010. This research was completed in May 2010.

31 Trociuk, ibid; Figueroa, ibid; Martin, ibid; Demers, ibid; Charkaoui, ibid; Health Services, ibid; and Nguyen, ibid. I also include Chaoulli, ibid, in this statistic. The Court in that case initially issued an immediate invalidation, but in a separate, unreported judgment, stayed the effect of its decision for 12 months: see Judgment in Application for a Re-hearing (4 August 2005), online: <http://scc.lexum.org/ en/news_release/2005/05-08-04.3re.wpd/05-08-04.3re.wpd.html>. No reasons were given for the latter judgment. 
Were the more recent Supreme Court decisions concerning suspended declarations to have remained true to the principles of Manitoba Language Reference, Swain, and Schachter, we might infer that the present landscape of Charter litigation involves a high degree of danger to the public interest necessitating the avoidance of precipitous statutory invalidations. It is not clear, however, that the subject matter of recent Charter litigation is so different from its predecessors in this respect. Rather, what has occurred is a reorientation in the objectives motivating courts to utilize suspended declarations, which in turn has spurred their proliferation. As Ryder observes:

[T] [Se [Supreme] Court has placed the division of institutional responsibility objective at the fore of its consideration of suspended declarations of invalidity. If the Court chooses to issue an immediate declaration of invalidity, it is the Court's ruling that establishes the new Charter-compliant legal status quo. A suspended declaration is often preferable, the Court has said, when the law could be brought into compliance with the Charter a number of different ways. ${ }^{32}$

It will be recalled that in Schachter, the availability of multiple options for curing the constitutional defect did not weigh on the Court's initial selection of remedy (striking down) or on its decision that the remedy should be temporarily suspended. Indeed, the Court specifically cautioned against consideration of "the role of the courts and legislature" in deciding to issue a suspended declaration. By bringing these considerations into the analysis, the courts refocus their inquiry on considerations of institutional role and capacity, and away from the primacy of the public interest.

Several Supreme Court decisions cited by Ryder are indicative of this trend. He notes, for example, that in the dissenting decision in Egan $v$ Canada, ${ }^{33}$ Justice Iacobucci

would have changed the definition of spouse in the Old Age Security Act to include same-sex couples through a combination of severance and reading in. He would have suspended the coming into force of the new definition for one year because it was an "issue of public policy" on which "some latitude ought to be given to Parliament to address the issue and devise its own approach to ensuring that that the spousal allowance be distributed in a manner that conforms with the equality guarantees of the Charter."34

Similarly, writing for the majority in Eldridge $v$ British Columbia $(A G),{ }^{35}$ Justice La Forest "held that it was appropriate to suspend the declaration 'to enable the government to explore its options to formulate an appropriate response." "36 Finally, in Dunmore v Ontario (AG), ${ }^{37}$ "rather than issuing an immediate declaration of invalidity that would have restored the collective bargaining rights of agricultural workers, Bastarache J. suspended the declaration of invalidity for 18 months to enable the legislature to decide how it wished to respect those workers' freedom of association., 38

Ryder, supra note 26 at 275.

[1995] 2 SCR 513 [Egan].

Ryder, supra note 26 at 278, citing Egan, ibid at 623.

[1997] 3 SCR 624 [Eldridge].

Ryder, supra note 26 at 279, citing Eldridge, ibid at para 96.

2001 SCC 94, [2001] 3 SCR 1016 [Dunmore].

Ryder, supra note 26 at 279. 
It should be evident that in each of these cases, an immediate declaration of invalidity would have posed no danger to the public, disruption to the rule of law, or deprivation of existing benefits to deserving individuals. It would, rather, have given immediacy to the equality rights of same-sex couples under old age security legislation, to the rights of the deaf to receive intelligible services in British Columbia hospitals, and to the rights of agricultural workers to collectively organize. By necessity, such immediate remedial dispositions by the Court would also have altered the status quo "on the ground," and impacted the range of policy choices available to government had it wished to respond legislatively to the decisions. It would seem that this potential impact or constraint on government discretion, rather than concern for public harm, was what motivated the use of suspended declarations in these cases.

Not all commentators on the expanded usage of suspended declarations view it in an entirely negative light. Sujit Choudhry and Kent Roach suggest that

[The] unannounced, yet clear shift in the rationale for suspended declarations of invalidity is to be welcomed, albeit with some cautions and caveats. In our view, it fits into a conception of institutional relationships under the Constitution in which both legislatures and courts take joint responsibility for ensuring compliance with constitutional norms. The suspended declaration of invalidity can be viewed as a form of legislative remand, whereby unconstitutional legislation is sent back for reconsideration in light of the court's judgment. At the same time, however, the court does not abdicate the responsibilities of judicial review. It formulates a remedy that will come into effect should the legislature not enact constitutional legislation by the court's deadline. ${ }^{39}$

Similarly, Peter Hogg, Allison Bushell Thornton, and Wade Wright view the expanded use of suspended declarations as sitting well with their "dialogue" theory of the interaction between courts and legislatures. ${ }^{40}$ That theory responds to critics of so-called "judicial activism” by pointing to the features of Canadian constitutionalism that enable ready legislative responses to and constraints upon judicial decisions. ${ }^{41}$ The authors state the following with respect to suspended declarations:

We conclude that the idea of dialogue has been influential in guiding the courts in their increasing use of suspended declarations of invalidity. A purpose of the suspension, and often the only purpose, is to enable the legislature to respond directly to a holding of invalidity. The court recognizes that a range of corrective laws is possible, and that the legislature is better placed than the court to select the appropriate remedy. Although an unconstitutional law is maintained in force for a short time, the Charter is still respected, because if no new law is enacted by the time the period of suspension ends, the declaration of invalidity takes effect. If a new law is enacted in response to the holding of invalidity, that law must comply with the Charter. $^{42}$ Constitutional Remedies” (2003) 21 SCLR (2d) 205 at 233.

40 Peter W Hogg, Allison A Bushell Thornton \& Wade K Wright, "Charter Dialogue Revisited - Or 'Much Ado About Metaphors”” (2007) 45:1 Osgoode Hall LJ 1 at 14-18 [Hogg et al, "Dialogue Revisited"].

$41 \quad$ See Peter W Hogg \& Allison A Bushell, “The Charter Dialogue Between Courts and Legislatures (Or Perhaps The Charter of Rights Isn't Such a Bad Thing After All)” (1997) 35:1 Osgoode Hall LJ 75 [Hogg \& Bushell, "Dialogue Theory”]; Hogg et al, "Dialogue Revisited,” ibid. 
Thus, while commentators take different views on the desirability of the courts' evolved approach to suspended declarations, there is general consensus that the dominant, contemporary approach is motivated primarily by institutional considerations. That is, Ryder, Hogg et al, Choudhry, and Roach each observe a departure from the categories in Schachter and increasing enforcement of the idea that it is the role of the legislature to craft remedial solutions to a judicial declaration of invalidity, with the courts enabling them in this task by using suspended declarations as an instrument of remand.

Assumptions about the respective roles of courts and legislatures must be approached with a careful, critical eye. It is one thing for courts to utilize suspended declarations when they feel genuinely unable to devise an appropriate remedial solution to a constitutional infraction, owing, for example, to their lack of policy expertise or resources. In Dixon, British Columbia Chief Justice McLachlin (as she then was) noted the propriety of allowing the legislature to determine the precise features of a new system of electoral boundaries; indeed, this consideration supplemented her concern that an immediate declaration of invalidity could precipitate an electoral crisis, and justified the issuance of a suspended declaration. ${ }^{43}$ Remand of remedial issues to the legislature in such a case, although departing from the strict categories of Schachter, may nevertheless honour the public interest to the extent that the latter is served by an optimal "institutional division of labour." ${ }^{44}$ The same may be true in cases where the policy implications flowing from a declaration of invalidity are exceedingly complex, demanding administrative resources and expertise that exceed the capacities of the courts. This has been the case with some decisions concerning Aboriginal rights, where the judicial enforcement of certain rights can have ripple effects upon others that are difficult to reconcile without detailed deliberation or consultation with the communities affected. ${ }^{45}$ In such instances, a suspended declaration may serve the dual purpose of insulating certain rights against adverse effects while facilitating the legislature in a complex policy task.

The considerations animating such cases differ, however, from the simple assumptions that legislatures possess a constitutional prerogative to devise the remedy following a declaration by the courts, and indeed that it would be inappropriate for courts to impose immediate remedies themselves. The latter assumption mirrors the jurisprudence of some countries, such as Great Britain, where courts are limited to providing only declaratory relief in matters of constitutional rights. Canada has adopted an expressly different constitutional structure. It is important to stress that immediate declarations of invalidity were, until recently, the status quo in Canadian constitutional jurisprudence, both in respect of Charter litigation and in division of powers cases. Unless the very propriety of the courts' use of this power is to be overturned, then the remand of remedial discretion to the legislature should require specific justification. That is, there should be reasons relating to the particular facts of each case explaining why a suspended declaration is justified as a tool of remand. 
In the following sections, I consider the use of suspended declarations by the Supreme Court during the past decade, ${ }^{46}$ together with one recent decision of the Court of Appeal for Ontario. This review suggests that serious problems arise in the present use of suspended declarations. The first type of problem relates directly to the concern outlined above: that courts evoke an institutional assumption commanding remand of remedial discretion to the legislatures, without providing a genuine explanation as to why the assumption is warranted. I refer to this as a problem of "inadequate reasoning," owing to the failure of the courts to provide real, satisfactory reasons conveying the merits of remand. The second type of problem concerns cases in which the courts utilize suspended declarations in order to remand remedial decision-making to the legislatures, but where the assumptions underlying remand prove to be ill-founded. I refer to these as cases of "flawed institutional assumptions." Finally, while all misuses of suspended declarations offend constitutional rights by enabling their unwarranted temporary suspension, in certain cases this offence is especially pronounced. I refer to these as cases of "injury to Charter rights," which include cases in which suspended declarations may actually be justified, but in which the courts have failed to take available steps to minimize their harsh consequences.

It should be borne in mind that the above problems are interrelated and do not describe distinct compartments. A case that suffers from inadequate reasoning may also display flawed institutional assumptions and fail to ensure appropriate protection for Charter rights. Although the cases considered below are presented under headings for which they are particularly illustrative, I also attempt show their linkages to related problems in the use of suspended declarations.

\section{The Problem of InAdequate ReAsoning}

The absence of adequate reasons justifying the use of a suspended declaration is the most pervasive problem evident in recent case law. The problem has been especially pronounced in the jurisprudence of the Supreme Court, although it is not confined to decisions at that level. The following cases demonstrate the problem.

\section{FIGUEROA V CANADA}

The problem of inadequate reasoning is well-illustrated by the Supreme Court's 2003 decision in Figueroa. Figueroa concerned a challenge to provisions of the Canada Elections $A c t^{47}$ that limited "registered party" status to political parties fielding candidates in at least 50 federal ridings. Parties not meeting this definition were denied certain benefits, including the right to issue tax receipts for political donations, the right of candidates to transfer unspent election funds to their parties rather than remitting the funds to the federal government, and the right of candidates to list party affiliation next to their names on election ballots. ${ }^{48}$ The applicant, the leader of the Communist Party of Canada, challenged the 50 candidate threshold on the basis that it infringed the right to vote. A majority of the Court

46

One Supreme Court decision included in my review, Corbiere, ibid, precedes this time period. Although decided in 1999, I have given particular attention to this case because it is uniquely illustrative of the problem of flawed institutional assumptions, discussed below. RSC 1985, c E-2, as repealed by SC 2000, c 9, s 576.

Figueroa, supra note 30 at para 8. 
agreed, finding that the barriers which the threshold imposed were at odds with section 3 of the Charter. The Court also systematically dismissed each of the federal government's attempts to justify the threshold under section 1, finding that in each case no rational connection lay between the threshold and the section 1 arguments proffered by the Crown.

It is significant that the federal government failed to establish a rational connection between the 50 candidate threshold and its justificatory arguments under section 1 . One would think that a legislative provision found, after exhaustive reasons, to make no rational contribution to any legitimate purpose could be struck down immediately without fear of adverse consequence. Yet this was not the result of the Court's ruling. Instead, the Court found the impugned provisions to be constitutionally invalid, but held: "The declaration of unconstitutionality is suspended for 12 months in order to enable the government to comply with these reasons." ${ }^{49}$ No additional reasons were given in support of the suspended declaration.

There are several possible explanations for the Court's decision to suspend its declaration of invalidity in Figueroa. For one thing, the federal government had already begun the process of amending the impugned legislation to impose only a 12 candidate threshold. Without deciding upon the legitimacy of this amendment, the Court may have wished to allow the legislative process to run its course. This would have been the de facto result, however, even if the Court had given its decision immediate effect. The only difference would have been that prior to the enactment of the revised law, no candidate threshold would have been in place. To understand why the Court may have wanted to avoid this result, we must question what the implications could have been of eliminating the candidate threshold altogether. The Court alluded briefly in its reasons to the fact that the matters complained of by the applicant — the inability to issue tax receipts, transfer excess funds to the party, or list party affiliation on ballots - were not the only consequences of being denied "registered party" status. Registered parties also benefited from "the right to free broadcast time, the right to purchase reserved broadcast time, and the right to partial reimbursement of election expenses upon receiving a certain percentage of the vote. ${ }^{, 50}$ The immediate invalidation of the candidate threshold would have enabled all newly qualified registered parties to access these benefits, which were not the subject of the litigation, and which were thus not included in the Court's analysis. Perhaps the Court felt that some harm could lie in this effect. It is also possible that the Court was concerned for possible unfairness that might result from immediately enabling newly qualified parties to obtain registered status only to have it taken away by future legislative amendment; or that the potential for such unfairness might create an undue political obstacle to future legislative action. The problem is that none of these explanations were actually given, let alone given in a manner that stated why they were of such importance to justify continued suspension of a constitutional right.

In sum, we cannot know why the Court issued a suspended declaration in Figueroa because the Court did not tell us. The desire to give the government "time to comply" with the judgment is no explanation, because compliance would have been the de facto result of immediate invalidation. Instead, the government was given licence to maintain 
unconstitutional restrictions against the Charter rights of citizens for a further year. This result is not trifling. It meant that during the suspension period (which, as it turned out, included a federal election) marginal political groups and the citizens who supported them were deprived of their full rights to participate in the political process. At worst, Figueroa contributed to the continued restriction of those rights without legitimate basis. At best, the Court failed to explain how that restriction was justified.

\section{FRASER V ONTARIO (AG)}

The Court of Appeal for Ontario's 2008 judgment in Fraser v Ontario (AG) ${ }^{51}$ suffers from similar inadequacy. Fraser concerned a challenge to Ontario’s Agricultural Employees Protection Act, 2002, ${ }^{52}$ which was enacted following the Supreme Court's decision in Dunmore, affirming the right of agricultural workers to collectively organize. ${ }^{53}$ The AEPA provides for the right of agricultural workers to form an employees' association, to assemble, and to make representations to their employers through the employees' association. ${ }^{54}$ It also prohibits employers from interfering with such activity. ${ }^{55}$ However, "[i]t does not impose an obligation on employers to bargain ... with an employees’ association."56 The applicants claimed that their collective bargaining rights were infringed. The Court of Appeal agreed with the applicants, and struck down the AEPA for violating section 2(d) of the Charter. ${ }^{57}$ However, the Court also suspended its declaration, with Chief Justice Winkler holding:

I would suspend this declaration of invalidity for 12 months from the date of these reasons to permit the government time to determine the method of statutorily protecting the rights of agricultural workers to engage in meaningful collective bargaining. This is not a situation where there is only one appropriate response to this decision. It is up to the legislature to assess the options, taking into account constitutional, labour relations and other factors, and to design a constitutionally accepted model. The declaration of invalidity is suspended in recognition that such a process takes time. ${ }^{58}$

Admittedly, the Court's reasons for issuing a suspended declaration were more detailed than in Figueroa: the Court acknowledged that several options existed to cure the constitutional defect, that a range of factors weighed on those choices and, by implication, that the legislature was better suited than the court to navigate the options. Furthermore, the Court acknowledged that this process would "take time," and we may infer that the suspended declaration was intended to assist the legislature in taking the time it needed without obstacle or disruption.

This is not an entirely satisfying explanation, however. The legislature can always choose among remedial options by enacting a new statute even following an immediate declaration

(2008), 92 OR (3d) 481 [Fraser]. The Supreme Court has recently overturned the Court of Appeal's decision in Ontario (AG) v Fraser, 2011 SCC 20, 331 DLR (4th) 64.

SO 2002, с $16[A E P A]$.

Supra note 37.

Supra note 52, s 1(2).

Ibid, s 8

Fraser, supra note 51 at para 28.

Notably, the Supreme Court has recently reversed the Court of Appeal's decision, see supra note 51. As the Supreme Court did not find the AEPA to contravene the Charter, its decision does not address the issuance of a suspended declaration.

Fraser, supra note 51 at para 139. 
of invalidity. Giving immediacy to the rights of agricultural workers to collectively organize would not have changed this fact, although it would have changed the political and social landscape in which the legislature was forced to operate. These changes - the consequences of an immediate declaration of invalidity - should have been the focus of a complete explanation as to why a suspended declaration was justified. We know from the section 1 analysis in Fraser that although the AEPA had a pressing and substantial objective — the protection of the family farm and accommodation of the unique economic characteristics of farm enterprises ${ }^{59}$ — the impugned provision bore no rational connection to this objective. As such, its temporary preservation could not be justified in reference to the objectives of the AEPA: no injury can flow to the purported benefactors of a provision when the provision does not rationally serve their interests to begin with.

Rather, we must look for some other danger: that the immediate invalidation might have created de facto collective bargaining rights, for example, which exceeded what the Constitution required and created impediments to a more nuanced response by the legislature. A complete justification for the suspended declaration would have defined this concern, and then explained why it was of sufficient importance to justify continued suspension of the Charter right. Instead, the Court simply stated that it is "up to the legislature" to correct the defective legislation, without attempting to justify that proposition in reference to the particular facts of the case. As with Figueroa, it is discomfiting to think that Charter rights — in this case, the rights of particularly vulnerable people — would be withheld for one year based on an assumption when we do not know whether the assumption is accurate or justified. ${ }^{60}$

\section{NGUYEN V QUEBEC (EDUCATION, RECREATION, AND SPORTS)}

Nguyen concerned a challenge under section 23(2) of the Charter to Quebec's Charter of the French Language. ${ }^{61}$ The latter statute is intended to promote the French language in Quebec, and includes provisions that ensure the majority of Quebec's residents receive public education in French-language schools. The statute nevertheless contains exceptions permitting the attendance of English-language schools for individuals so entitled under section 23(2) of the Charter. In 2002 the statute was amended to address the problem of parents temporarily enrolling their children in unsubsidized, private English-language schools in order to benefit from an exemption allowing those children to then transfer into the public, English-language school system. The amended provisions stipulated that time

Ibid at para 122.

The Supreme Court's decision in Health Services, supra note 30, has strong similarities to Fraser. Health Services concerned a challenge to the Health and Social Services Delivery Improvement Act, SBC 2002, c 2, a statute introduced by the British Columbia government in 2002 to control the escalating cost of health care delivery in the province. The Act enabled the managers of health care institutions to reorganize their labour force using measures that might otherwise have been impeded by collective agreements and bargaining rights. The applicants, representing certain health sector employees, charged that the legislation violated their members' rights under section 2(d) of the Charter. The Court supported this allegation but suspended its declaration of invalidity, providing only the following brief reasons: "[W]e suspend this declaration for a period of 12 months to allow the government to address the repercussions of this decision" (Health Services, ibid at para 168). As with the cases considered above, the Court failed to articulate what the "repercussions" of its declaration of invalidity might be, why the legislature required insulation against those repercussions, and why the latter should have been given greater priority than the immediate enforcement of a Charter right. RSQ, с C-11. 
spent in unsubsidized private schools would not be taken into account in assessing eligibility for public, English-language education, nor would time spent receiving English-language education pursuant to special authorization by the province (for example, in cases of learning disability). The Court upheld the applicants' objections to these provisions, finding that they violated section 23(2). While the Court recognized that the promotion of the French language was a legitimate objective which might justify limitations to Charter rights, the impugned provisions went too far by posing an absolute prohibition that failed to account for the unique educational needs of individual children. The Court nevertheless suspended its declaration of invalidity for one year "[b]ecause of the difficulties this declaration of invalidity may entail”62 and “to enable Quebec's National Assembly to review the legislation.,"63

As with Figueroa and Fraser, the Court in Nguyen stated a proposition rather than providing an explanation. It alluded to "difficulties" that would arise upon an immediate invalidation, but did not define what those difficulties were, how the suspended declaration averted them, or why their aversion was of sufficient importance to displace immediate vindication of a constitutional right. While the Court expressly acknowledged "the dangers that the unlimited expansion of [unsubsidized private schools] could represent for the objectives of preserving and promoting the French language in Quebec, " ${ }^{64}$ it also found that a relatively small number of Quebec residents were actually taking advantage of this loophole to secure a place for their children in English-language public schools. ${ }^{65}$ Thus, it is not at all clear that the provision needed to be preserved as an interim safeguard while the legislature crafted a replacement. We are left to query what other harm might have resulted from the immediate invalidation so as to warrant its suspension.

\section{SUMMARY}

When courts issue suspended declarations on the basis that "[i]t is up to the legislature" to cure a constitutional defect, ${ }^{66}$ "to enable the government to comply" with a decision, ${ }^{67}$ or to "enable [the] National Assembly to review the legislation," 68 fundamental questions are left unanswered. Each of these statements conveys the implicit proposition that the immediate invalidation of a law is less desirable than remand of remedial decision-making to the legislature. None of them, however, explain why. None of them explain why the scenario that would result from an immediate invalidation of the impugned law is undesirable, either in terms of an intelligible harm to the public, or in terms of an obstacle that would be created to legislative discretion in crafting a reply. Moreover, none of them explain why it should be left to the legislature, rather than the courts, to devise the remedial solution to a declaration of invalidity. None of them explain the duration selected for the suspended declaration - why a 12-month period of suspension was considered appropriate in every case, when in Swain, where immediate invalidation would have produced an imminent danger, only a six-month suspension period was necessary. Finally, none of them

Nguyen, supra note 30 at para 46.

Ibid.

Ibid at para 43.

Ibid at para 42.

Fraser, supra note 51 at para 139.

Figueroa, supra note 30 at para 93.

Nguyen, supra note 30 at para 46. 
explain why the benefits secured by a suspended declaration should be given greater priority than the immediate vindication of Charter rights.

One suspects, reading the preceding cases, that the courts may not have thought deeply about the justifications of remand; that rather, the courts acted on a simple presumption about their own institutional limits and the relative jurisdiction and capacity of the legislatures. In Part III, below, I consider the core precepts of Canada's constitutional model to suggest that the courts' apparent presumption misconceives those precepts. I note for present purposes that at the very least, the cases mark a serious, unacknowledged departure from the principles of Schachter, Swain, and the Manitoba Language Reference, which required the courts to justify suspended declarations in reference to an intelligible public harm that would result from immediate invalidation. Perhaps more significantly, they mark a departure from the status quo that prevailed in Canada until the past decade: that a law found to be in violation of the Constitution immediately lost its force and effect.

In the context of administrative decision-making, the Supreme Court has stressed the importance of giving reasons when decisions impact significantly on the lives of individuals - for example, when immigration officials decide to order an individual's deportation. In Baker $v$ Canada (Minister of Citizenship and Immigration), ${ }^{69}$ the Court observed:

Reasons ... foster better decision making by ensuring that issues and reasoning are well articulated and, therefore, more carefully thought out. The process of writing reasons for decision by itself may be a guarantee of a better decision. Reasons also allow parties to see that the applicable issues have been carefully considered, and are invaluable if a decision is to be appealed, questioned, or considered on judicial review. ${ }^{70}$

Suspended declarations of invalidity have serious consequences for individuals because they sustain the limitation of their rights. One would think that, accordingly, the duty to give reasons enforced by the courts against administrative agencies should apply equally to their own conduct in issuing a highly consequential remedial measure.

\section{The Problem of FlaWed InStitutional AsSUmptions}

The preceding cases suggest the emergence of a judicial presumption in favour of delegating remedial decision-making to the legislatures by using the suspended declaration as an instrument of remand. I have argued that the cases fail to offer reasons explaining, let alone justifying, such a presumption. Clearer explanations are only the first step in improving the dominant approach to suspended declarations, however. As the discussion below demonstrates, even when the courts' reasons for remand are more evident, there is a danger that flawed institutional assumptions can undermine the very purpose of suspended declarations. 


\section{CORBIERE V CANADA (MINISTER OF INDIAN AND NORTHERN AFFAIRS)}

Corbiere provides the paramount example of a court issuing a suspended declaration based on institutional considerations. Corbiere concerned a challenge to then section 77(1) of the Indian Act, which restricted the right to vote in First Nations band elections to band members who were "ordinarily resident" on a reserve. ${ }^{71}$ The applicants were members of the Batchewana Band, who lived off-reserve, and claimed that their exclusion from band elections violated their right to equality under section 15 of the Charter. The Supreme Court found in favour of the applicants.

The remedial disposition of the case, however, presented a challenge. The applicants sought immediate vindication of their Charter rights, yet the Court's invalidation of section 77(1) of the Indian Act would affect all First Nations, not just the band of which the applicants were members. Specifically, the outright invalidation of section 77(1) would create a new, universal voting regime that might not be suited to the individual characteristics of every First Nations community. In response to these concerns, the Court opted to utilize a suspended declaration. It struck down section 77(1) of the Indian Act but suspended the effect of its declaration for 18 months to enable Parliament to consult with First Nations communities in devising a new legislative scheme. Justice L’Heureux Dubé's reasons gave detailed attention to the institutional relationship between courts and legislators:

\footnotetext{
There are a number of ways this legislation may be changed so that it respects the equality rights of nonresident band members. Because the regime affects band members most directly, the best remedy is one that will encourage and allow Parliament to consult with and listen to the opinions of Aboriginal people affected by it.... The principle of democracy underlies the Constitution and the Charter, and is one of the important factors guiding the exercise of a court's remedial discretion. It encourages remedies that allow the democratic process of consultation and dialogue to occur.... The remedies granted under the Charter should, in appropriate cases, encourage and facilitate the inclusion in that dialogue of groups particularly affected by legislation. In determining the appropriate remedy, a court should consider the effect of its order on the democratic process, understood in a broad way, and encourage that process.
}

The above principles suggest, in my view, that the appropriate remedy is a declaration that the words "and is ordinarily resident on the reserve" in s. 77(1) are invalid, and that the effect of this declaration of invalidity be suspended for 18 months. The suspension is longer than the period that would normally be allotted in order to give legislators the time necessary to carry out extensive consultations and respond to the needs of different groups affected. ${ }^{72}$

The Court acknowledged that the issuance of a suspended declaration was a "serious matter" enabling an unconstitutional state of affairs to continue for a temporary period, ${ }^{73}$ but observed that any concerns for the violation of individual equality rights during the suspension period could be raised by fresh litigation. ${ }^{74}$ 
Unfortunately, the actual results of remand to the legislature did not accord with the Court's intentions. Despite the Court's apprehension that the federal government would need a lengthy suspension period in which to complete consultations, the government did not commence such consultations until seven months after the Court's decision. ${ }^{75}$ The government's response consisted of two stages; the first involving consultations with four national Aboriginal groups, and the second involving the introduction of new regulations allowing off-reserve band members to vote in band elections by mail-in ballot, taking effect upon the expiry of the 18-month period set by the Court. ${ }^{76}$ The federal government also provided training to certain bands in implementing the revised election procedure. ${ }^{77}$ Notably, the government did not engage in a more complex consultation process concerning the section 35(1) issues raised before the Court, nor in respect of other matters that the Court anticipated might bear on a reformed voting policy, such as differentiation in voting rights between reserve and non-reserve residents with respect to issues that affected only one group. ${ }^{78}$ The latter point is significant. It means that the new electoral regime instantiated by the government was virtually identical to what would have resulted from the immediate invalidation of the impugned law. The only differences were that the government designated mail-in ballots as the method of voting, and provided certain First Nations communities with training assistance. And, of course, that off-reserve band members had to wait an additional 18 months before being able to exercise their voting rights. In the meantime, the equality disputes which the Court anticipated might occur during the suspension period did, in fact, arise, with several groups initiating "satellite litigation" to prevent the enforcement of the impugned portion of the Indian Act during the period of suspension. ${ }^{79}$

It is intriguing to speculate what the effects of a more robust remedial disposition would have been. Had the Court not suspended its declaration of invalidity, all off-reserve members of Aboriginal bands would have become immediately entitled to vote in band elections. It would have become immediately incumbent upon bands to devise means of enabling this right - for example, by mail-in ballot or remote polling stations. Some bands may have been prompted to bring court applications to assert special section 35(1) rights limiting the extension of their voting systems. The federal government may have been required to enact reply legislation, and to have done so on a fast-tracked basis. To be sure, the immediate enforcement of the Court's decision would have created circumstances of uncertainty and administrative complication. It is not clear, however, that the latter would have been worse than the effects of the Court's delayed declaration. What is certain is that an immediate declaration would have brought immediate, enforceable vindication to the rights of the Charter claimants and to other similarly situated individuals. Those individuals - for whom the costs of accessing justice are the most burdensome - would likely not have had to initiate fresh litigation to enforce their rights. Rather, the costs of administrative adjustment or of initiating further court proceedings would have been borne by those responding to the Court's declaration — the federal government and Aboriginal bands — a seemingly

$75 \quad$ See Kent Roach, "Remedial Consensus and Dialogue Under the Charter: General Declarations and Delayed Declarations of Invalidity” (2002) 35:2 UBC L Rev 211 at 246 [Roach, "Remedial Consensus"].

Ibid at 245.

Ibid.

Ibid.

Ibid at 248. 
appropriate allocation given the resources of these parties and their situation on the "losing" side of the Charter claim.

\section{CHARKAOUI V CANADA (MINISTER OF CITIZENSHIP AND IMMIGRATION)}

An ironic consequence of the Court's remand of remedial decision-making to the federal government in Corbiere was that it contributed to the occurrence of future litigation which it was intended to forestall. The same may turn out to be true of the Supreme Court's more recent decision in Charkaoui. Charkaoui concerned a challenge under section 7 of the Charter to Canada's regime of security certificates, which permit the detention and possible deportation of non-citizens on the basis of their alleged danger to national security. Under the regime, individual certificates are subject to confirmation by a judge. The individuals who are subject to the certificates are not, however, entitled to disclosure of the evidence on which the certificates are based. The applicants in Charkaoui successfully challenged this aspect of the regime as violating their right to security of the person. The Court noted several less restrictive means by which the sensitive information underlying the certificates could be protected from disclosure while simultaneously affording the individuals a full answer and defence. ${ }^{80}$ The existence of these alternatives led the Court to conclude that the infringement of the applicants' section 7 rights could not be justified. Rather than striking the regime down outright, however, the Court suspended its declaration "in order to give Parliament time to amend the law." ${ }^{\prime 1}$ The suspension was to take effect for one year.

Like the cases considered earlier concerning the problem of inadequate reasoning, Charkaoui contains scant explanation for the Court's use of a suspended declaration. The Court did not, for example, suggest that immediate invalidation of the security certificate regime would result in the release of potentially dangerous individuals into the public. ${ }^{82} \mathrm{We}$ can infer, however, that considerations of institutional roles were central in the Courts' analysis. The Court canvassed a number of less impairing alternatives that Parliament might consider in enforcing its security certificate regime, then remanded the issue to Parliament to craft a long-term solution. Implicit in the Court's decision was the assumption that Parliament was better suited to select from among the alternate regimes that would result in a lesser impairment of Charter rights. Unfortunately, a review of the effects of the Court's decision casts doubt on the veracity of that assumption.

The legislative response to Charkaoui, Bill C- $3,{ }^{83}$ has been heavily criticized. ${ }^{84}$ It suffices for present purposes to point out that Parliament adopted what Roach terms a "minimalist" response to the Court's decision, ${ }^{85}$ by selecting the least robust of the remedial models

80

81

82

84

See discussion supra note 30 at paras 70-84 of the Court's ruling.

Ibid at para 140 .

Had the Court offered such an explanation, it might have reconciled well with the standard set by Swain. However, as discussed in the next section, the Court's use of a suspended declaration would have remained problematic, because unlike Swain, it was not combined with interim relief to mitigate the harsh consequences of suspension.

An Act to amend the Immigration and Refugee Protection Act, SC 2008, с 3.

For a full and critical review of the legislation, see Kent Roach, "Charkaoui and Bill C-3: Some Implications for Anti-Terrorism Policy and Dialogue Between Courts and Legislatures” (2008) 42 SCLR (2d) 281 [Roach, “Implications”]; Craig Forcese \& Lorne Waldman, “A Bismarkian Moment: Charkaoui and Bill C-3” (2008) 42 SCLR (2d) 355.

Roach, "Implications," ibid at 290. 
considered by the Court. In the scheme enacted by Parliament, special advocates could review any confidential material provided by the Crown to the judge overseeing a certificate hearing, but they could not discuss the material with individual detainees or with any other parties without leave of the judge.$^{86}$ Moreover, the special advocates were limited in their ability to seek disclosure of additional materials possessed by the Crown - their rights were limited to only those materials that would be viewed by the judge, as opposed to all materials potentially relevant to giving a full defence.

The Court's decision to remand remedial decision-making to Parliament, thus, had a counterintuitive effect in that Parliament enacted a scheme that remanded a host of administrative decisions back to the courts (both to the judges who conduct security certificate hearings and to those performing judicial review on appeal). ${ }^{87}$ This would seem to belie Parliament's presumed institutional capacity in crafting nuanced policy responses in matters of national security, or at least Parliament's own confidence in the exercise of that capacity. As in the case of Corbiere, the parties who will likely bear the greatest cost of a decision-making approach that remands contentious issues to the courts are the Charter claimants themselves (already, in most cases, society's most vulnerable members) rather than the government.

\section{SUMMARY}

Corbiere and Charkaoui both illustrate a counterintuitive result of remanding remedial decision-making to legislatures. Rather than making full use of their administrative and human resources to craft sophisticated, comprehensive responses to constitutional declarations by the courts, there is a risk that legislatures will do only the minimal amount necessary to achieve constitutional compliance. The motivations for a minimalist approach may vary. In the case of Corbiere, it appears as though Parliament may have taken advantage of the suspended declaration simply to delay the correction of defective legislation, failing to use the suspension period to initiate more robust consultations. In Charkaoui, the minimalist approach may have had more to do with the minority position of the federal government at that time, and the difficulty of building Parliamentary consensus on controversial matters of national security (which in turn enhanced the attraction of more modest legislative aims).

Perhaps it should come as no surprise that governments, having enacted constitutionally invalid legislation to begin with, will wish to minimize subsequent amendments to their work. In any case, the most important insight to draw from Corbiere and Charkaoui is that the use of suspended declarations as instruments of remand can inflict unintended costs upon existing and future Charter claimants. Not only are those individuals forced to accept the continued suspension of their rights, they bear the costs of initiating future Charter actions when a minimalist legislative response fails to comprehensively satisfy the dictates of the Constitution. Often these individuals are already the most marginalized members of society, financially and otherwise. This allocation of remedial burden is skewed, and directly contradicts the goal of engaging citizens in the process of democratic "dialogue.” 
It will be recalled that several commentators believe the expanded use of suspended declarations reconciles well with a "dialogic" relationship between the courts and legislatures. Yet when dialogue theory is evoked as a descriptive metaphor for the relationship between courts and legislatures, ${ }^{88}$ it challenges us to recall that legislatures always have the ability to reply to judicial declarations. ${ }^{89}$ The possibility of legislative reply can militate for or against a suspended declaration, depending on the particular facts of a case. The challenge for the courts is to consider what the effects of an immediate declaration of invalidity might be and to weigh those against both the prospective benefits and the prejudices that will result from suspension. No doubt in some cases, this will be a challenging exercise, with the prospect of reasonable disagreement about which option a court should select. However, the cases considered in this section demonstrate that the possibility of the legislatures bringing their particular administrative and human resources to bear on a problem does not, in itself, support a presumption that they will supply better remedial solutions than the courts.

\section{E. The Problem OF INJURy TO CHARTER RightS}

Injury to Charter rights is the most embracing of the problems arising from the present usage of suspended declarations of invalidity. In all of the cases considered so far, the justifications for suspended declarations have been cast into doubt. A suspended declaration issued without adequate justification is inherently offensive to constitutional rights, as it permits the unwarranted restriction of those rights to be preserved. Thus, in Figueroa, the applicants suffered the continued denial of their right to full participation in Canada's political process; in Fraser, the applicants suffered continued restriction of their right to collectively bargain. As cases like Corbiere and Charkaoui foreshadow, suspended declarations may also contribute to an unjust allocation of the burden of Canada's Charter commitments, as marginalized individuals and groups are forced to bring incremental litigation in response to a minimalist legislative approach, escalating both the time and cost of instilling Charter compliance.

This section is concerned with an overt example of injury to Charter rights - the dogmatic refusal to combine suspended declarations with interim relief under section 24(1) of the Charter — which starkly illustrates the consequences that may be suffered by rightsclaimants within a period of suspension. The Supreme Court's decision in Demers provides a useful starting point for this discussion.

See Richard Haigh \& Michael Sobkin, "Does the Observer Have an Effect?: An Analysis of the Use of the Dialogue Metaphor in Canada’s Courts” (2007) 45:1 Osgoode Hall LJ 67. Haigh and Sobkin point out that "dialogue" is intended as a descriptive metaphor capturing the dynamic interaction of courts and legislatures. It is not intended as a prescriptive metaphor - that is, one commanding a particular approach to judicial review. When the metaphor is applied prescriptively by the courts - for example, to justify deference to the legislature - it leads to confusing and inconsistent outcomes. For this reason, Haigh and Sobkin caution against the liberal evocation of "dialogue" references in court judgments.

89 As Ryer points out: "Whether the operation of a declaration of invalidity is immediate or delayed, a legislature faces the exact same range of constitutional possibilities. It is free to disagree with the legal regime that follows upon a Court's choice of an immediate declaration of invalidity and substitute some other constitutional option.” Supra note 26 at 281. 


\section{RVDEMERS}

Demers concerned an accused individual who suffered from Down syndrome and who had been found mentally unfit to stand criminal trial. At the time, the Criminal Code imposed a complex procedure for the management of the mentally unfit accused. Upon a finding of unfitness, either a court or a review board was required to conduct a disposition hearing to determine whether, and under what conditions, the accused should be detained. ${ }^{90}$ A review board could not order the unconditional discharge of the accused, however, and was required to reconvene once every year to determine whether a change in the accused's condition warranted a revision to its disposition. ${ }^{91}$

The result of this regime was that permanently unfit accused persons could remain in the criminal justice system indefinitely. An accused remanded to a review board would be continually subjected to an annual hearing before the board even if he or she would never become capable of standing trial, and even if he or she posed no danger to the public. The only possible relief was that the Crown might abandon the case, a matter entirely outside of the accused's hands. The Court accordingly found that the regime offended section 7 of the Charter. As the regime offended the Charter for overbreadth, it was incapable of meeting the standard of minimum impairment and could not be justified under section $1 .^{92}$

Applying Schachter, the Court opted to suspend its declaration of invalidity in Demers for 12 months in order to enable Parliament to amend the offending Criminal Code provisions. Its concern was that an immediate invalidation of the regime would create a legal "lacuna" resulting in the release of dangerous persons. ${ }^{93}$ The Court also observed that Parliament was best suited to effect "complicated consequential amendments" to the legislation. ${ }^{94}$ The Court declined, however, to provide an interim remedy such as a stay of proceedings to the accused during the period of its suspended declaration. Citing Schachter's treatment of the interaction between section 52 and section 24(1), the Court found that " $[t]$ his rule precludes courts from granting a s. 24(1) individual remedy during the period of suspended invalidity.... In our view, there is no reason to revisit the wisdom of the Schachter rule in the present case. There is no evidence that government acted in bad faith or abused its powers."

It is true that the Court in Schacter declined to provide section 24(1) relief to the claimant. However, the claimant in that case sought monetary damages. Had he received such an award, he may have been placed in a better position than other individuals adversely impacted by the unconstitutional legislation, as the Court could not anticipate the remedial regime that Parliament would enact. Demers, on the other hand, concerned the enforcement of a substantive right to personal security and procedural fairness. The Court's own reasons underscored the significance of this infringement, noting that individuals kept in the criminal justice system "will be subject to anxiety, concern and stigma because of the criminal proceedings that hang over them indefinitely." 96 The result of the Court's suspended 
declaration was that individuals who had been found to pose no danger to the public, and to be permanently incapable of standing trial, continued to be subjected to the stigma and anxiety of the criminal system for a further year. It is not at all clear how affording these individuals with interim relief would have undermined Parliament's long-term remedial solution or posed any prejudice to the public.

Fortunately, the accused in Demers was not detained but had been released under certain conditions. Nevertheless, the Court's decision to suspend its declaration did not provide him with immediate relief from the anxieties and stigmas of prosecution, nor did it provide relief to similarly situated individuals or to those who faced the more severe circumstances of detention. $^{97}$

\section{CHARKAOUI V CANADA}

Charkaoui can also be taken as an example of the injury inflicted on Charter rights when courts decline to combine section 52 and section 24(1) remedies. In an alternate disposition to the case, the Court might have suspended its declaration of invalidity, but provided immediate relief to detainees under the security certificate regime by imposing an interim right to special counsel. This would have protected existing interests under the regime such as public safety (although that interest was not evoked in the Court's reasons on the suspended declaration). However, it would also have required that the Court provide an integrated section 52 and section 24(1) remedy. The absence of such a remedy had disturbing implications. The most severe consequence of the security certificate regime then in place was that a certificate, upon judicial confirmation, could become a deportation order and result in the deportation of individuals to jurisdictions practicing torture. It is not clear that the Court's decision in Charkaoui imposed any safeguard against this consequence arising during the period of its suspended declaration.

The irony of the Supreme Court's reluctance to combine section 52 and section 24(1) remedies is that it extended, at least in Demers, from a stringent application of Schachter when the courts have been content to depart from Schachter when deciding to issue a suspended declaration in the first place. Chief Justice Lamer's decisions in other cases, such as Swain and Rodriguez v British Columbia (AG), ${ }^{98}$ should make clear that he did not intend a "hard-and-fast" application of the reservations he expressed in Schachter about combining section 52 and section 24(1) remedies. Swain involved the apprehension that an immediate declaration of invalidity would result in the release of dangerous individuals into the public. Nevertheless, the Court issued only a six month suspension (as opposed to 12 months in Demers), provided an automatic right for detainees to habeas corpus following a detention of 30 days, and allowed either party to apply to the Court for variation of its order should any problems arise during the period of suspension. ${ }^{99}$ In Rodriguez, Chief Justice Lamer was at pains to limit the scope of his earlier statement in Schachter that section 52 and section 24(1) adherence" to the Schachter rule and emphasized that "[c]orrective justice suggests that the successful applicant has a right to a remedy.” Ibid at paras 96, 101. In the result, Justice LeBel would have issued a suspended declaration, but require that all permanently unfit accused who did not pose a danger to the public receive to a stay of proceedings within 30 days of being found unfit (ibid at para 107). 
remedies would rarely be combined. Having found in his dissenting reasons that the criminal prohibition against physician-assisted suicide violated the Charter, Chief Justice Lamer held that a suspended declaration combined with a constitutional exemption was the appropriate remedial disposition of the case. He observed that "[t]he cases to date are unclear on the precise status and rights of persons subject to the law during a period of suspended invalidity," ${ }^{100}$ and considered a constitutional exemption to be necessary because "[t]o create a right without a remedy is antithetical to one of the purposes of the Charter which surely is to allow courts to fashion remedies when constitutional infringements occur."101

\section{SUMMARY}

The cases conveying problematic instances of suspended declarations - whether due to inadequate reasoning, flawed institutional assumptions, or injury to Charter rights — might all be criticized as affirming rights without providing meaningful, correlative remedies. This is not to minimize the force of a purely declarative remedy, even when the latter has a delayed effect. To be sure, declaration that a right has been infringed is a powerful and important remedy in itself: it signifies clearly that the government has done something wrong, vindicates the claimants' complaint, and behooves the government to undertake corrective measures not just for the complainant but for others in a similar position. Nevertheless, when the reasons for suspending a declaration of invalidity are not clearly set out, or when they rest on flawed assumptions or fail to include adequate safeguards against their harsh effects, it is impossible to escape the impression that complete, satisfactory justice has been denied to the successful claimant. In the final section of this Part, I return to the relationship between rights and remedies to discuss the unique challenges confronting courts in the exercise of remedial discretion and how those are manifested in decisions to issue a suspended declaration.

Before proceeding, however, an additional harm that is not capable of easy demonstration nevertheless warrants brief mention. This is the danger that suspended declarations will contribute to a chilling effect on constitutional litigation in Canada. Given the onerous costs of bringing a constitutional challenge to court, the persistence required in seeing litigation through to the Supreme Court, and the emasculation of institutional support for constitutional claimants, such as the Court Challenges Program, there is a legitimate risk that suspended declarations add to the already steep disincentives against individuals initiating constitutional challenges. At the very least, it must be frustrating for individual litigants who have incurred stress, expenditure, and risk over years of litigation in order to have their claims vindicated, only to have to wait a further year to receive a remedy.

\section{F. SUSPENDED DECLARATIONS AND THE DILEMMAS OF REMEDIAL DISCRETION}

Each time a court contemplates the use of a suspended declaration, it faces a common set of concerns. It will be clear from the review above that the courts do not always succeed in giving express or deliberate attention to these concerns, which are sometimes subsumed by 
ill-founded assumptions. Nevertheless, I suggest that the following are questions that should arise when judges face the decision whether to issue an immediate or a suspended declaration of invalidity:

- Will harm to the public flow from an immediate declaration of invalidity, either in the form of one of the "categories" summarized in Schachter or in some other form? Can that harm be averted by issuing a suspended declaration?

- $\quad$ Are there multiple options for curing the constitutional defect? If so, does an immediate declaration of invalidity impose one of those options at the expense of others? Will an immediate declaration create impediments to the legislature crafting future laws that might improve the remedial situation by a more nuanced reply?

- If any of the above factors militate in favour of a suspended declaration, is it possible to provide the claimants with immediate relief via conditions built into the section 52 declaration or via the discretionary powers of section 24(1)? Can such relief be extended not just to the claimants, but to similarly situated individuals? If such relief is provided, will it inflict any injury in the terms of Schachter or in some other form? Will it frustrate the ability of the legislature to craft an optimal remedy via reply legislation?

Considering the above questions, it is perhaps easier to understand why the courts have departed from the categories outlined in Schachter. Schachter acknowledged the possibility that a suspended declaration would be appropriate where multiple options existed for the legislature to cure an invalid law, but required additionally that immediate invalidation threaten to erase the benefits of existing recipients under the legislative scheme. Otherwise, the Schachter categories focus purely on issues of public harm - imminent danger to the public or to the rule of law - without regard to the possible constraints an immediate declaration might impose upon long-term remedial discretion. A case such as Corbiere, for example, poses a challenge to the principles from Schachter because the adverse consequences it identifies - the convolution of Aboriginal rights in relation to a Charter right - cannot easily be categorized as a deprived benefit, public danger, or injury to the rule of law. Similarly, the possibility that immediate invalidation might create an obstacle to a subsequent, optimal remedy that requires legislative fashioning — for example, by establishing acquired rights that cannot easily be removed for reasons of fairness - is not readily accommodated under Schachter, because the latter cautions against considerations of institutional role in determining the propriety of a suspended declaration. ${ }^{102}$

However, it is important to recall that the Supreme Court in Schachter did not intend for the categories to stand as hard-and-fast rules. What animated each category was a concern to protect an important public interest or to avert a public harm. If the courts in subsequent

102 Ryder, supra note 26 at 285, addresses this problem:

[T] he Schachter ruling did not consider whether an immediate declaration of invalidity would have the practical effect of narrowing the range of choices the legislature could realistically contemplate in designing a new Charter-compliant legal policy. If a court issues and immediate declaration of invalidity, reliance and expectation interests may gather round the new legal regime, or its implementation may require the development of substantial administrative structures. 
cases had focused on these underlying principles, rather than feeling bound strictly to the categories of Schachter, they might have continued to draw meaningful guidance from the case.

Roach suggests that the courts have adopted two divergent approaches to suspended declarations of invalidity, with some judges struggling to fit all suspended declarations into the Schachter categories (what he calls “rule-based” remedial discretion), and others simply ignoring Schachter and issuing suspended declarations with little or no principled explanation (what he terms "strong" remedial discretion). ${ }^{103}$ The cases reviewed above suggest that the latter approach has come to dominate. Roach argues that the courts should instead focus on core principles governing the remedial exercise - a middle path between the two extremes. I agree, but argue that Schachter remains relevant to this enterprise.

Schachter's core principles of protecting the public interest and averting public harm are capable of embracing the remedial dilemmas outlined above. To be sure, some of those dilemmas probe the respective roles of the courts and legislatures, entering territory which Chief Justice Lamer cautioned was irrelevant to the issuance of a suspended declaration. But it is important to recall the context in which Chief Justice Lamer made these remarks — they followed his earlier direction that courts strive to preserve legislative intent through remedies other than invalidation, resorting only to the latter when this was impossible. It would appear Chief Justice Lamer felt that concern for the legislature's law-making prerogative was accounted for at this earlier stage, and that accordingly, the subsequent decision whether or not to suspended a declaration of invalidity should not be influenced by concern over institutional deference. When courts consider that their own institutional capacities prevent them from crafting an optimal remedy, or that an immediate declaration of invalidity would create a state of affairs that inhibits the legislature from pursuing such a remedy, the animating concern is not really deference but concern for an ideal solution to the constitutional infraction. The latter, clearly, is cognizable as a public interest, and the impediments and uncertainties produced by an immediate declaration - for example, unpredictable impacts on related rights, as in the Aboriginal cases — are cognizable as forms of public harm. The extension of the Schachter principles to embrace these cases is perhaps a purposive rereading of the dictates of the case, but it hardly stretches them beyond reason.

To be clear: when considering whether or not to issue a suspended declaration, I suggest that courts may consider their own limited institutional capacity to craft ideal remedies and the relative institutional strengths of the legislatures. The courts may legitimately demarcate the limits of their capacity based on jurisdiction - for example, concluding that a robust remedial disposition would be tantamount to creating a new policy scheme, and thus trench on legislative jurisdiction — or based simply upon the courts' relative weakness navigating the competing interests and uncertain consequences of a declaration of invalidity. However, the public interest must underlie this analysis; the courts must be able to say (and indeed, their reasons should state expressly) that unless a suspended declaration is used, the pursuit of an optimal remedy will be frustrated. 
For this reason, purely institutional considerations will never completely justify suspended declarations - a court should not be able to say "the legislature is best suited to craft a reply to this declaration, and therefore the declaration should be suspended.” This is because the legislatures always have the ability to respond to declarations of invalidity, even when the latter are immediate. Absent special circumstances, they should not need the suspension of a court's declaration (and its consequent suspension of constitutional rights) to enable them in this task. It is only when those special circumstances arise - a serious impediment to legislative discretion that will be produced by an immediate declaration, or a constitutionally intolerable harm consequent upon immediate invalidation — that a suspended declaration may be justified. This again brings us into the terrain of public interest and the aversion of harm: the public interest arises in the pursuit of an optimal remedy, the impediments to which (or any other adverse consequences inflicted by an immediate invalidation) can be understood as forms of public harm. Accordingly, when institutional considerations bear on the issuance of suspended declarations, they will always be combined with considerations of the public interest if the adverse effects of a suspended declaration are to be truly justified.

I noted earlier that suspended declarations of invalidity may sometimes be criticized as establishing a right without a remedy. This criticism is potentially unfair because, in the exercise of remedial discretion, courts are required to balance the interests of parties other than those to the immediate dispute, and when those interests are accounted for, perfect vindication of an impinged right may not be possible. Indeed, the necessity of accounting for parties other than those to the dispute is an endemic feature of constitutional litigation, where judicial decisions impact broad societal interests and not just the private affairs of disputing parties. Owen Fiss suggests that in the adjudication of constitutional questions, judges are not just the arbiters of individual disputants, but officials charged with giving meaning to public values: "[the judge] is a public officer; paid for by public funds; chosen not by the parties but by the public or its representatives; and empowered by the political agencies to enforce and create society-wide norms, and perhaps even to restructure institutions, as a way, I suggest, of giving meaning to our public values." ${ }^{104}$ Public values include those expressed in the Constitution, such as equality and fairness, that take tangible form when enforced by judges. Yet their enforcement is felt throughout society, posing a distinct challenge to the judge at the remedial stage: "The judge must be certain that the full range of [societal] interests is vigorously represented, but he need not turn his back on the constitutional claim or deny an effective remedy because each and every individual affected will not or cannot meaningfully participate in the suit.”105

Owen M Fiss, "Foreword: The Forms of Justice” (1979) 93:1 Harv L Rev 1 at 31.

Ibid at 41. Abram Chayes takes a similar view. He describes America's civil rights era as marking the advent of "public law litigation," and like Fiss, notes that public law or constitutional cases engage courts in remedial questions that go beyond the rectification of disputes between isolated parties:

In public law litigation, the dominant form of relief is prospective and affirmative rather than compensatory.... To be sure, the purpose of the decree is to rectify a course of conduct that has been found to abridge rights asserted by the plaintiffs. But the trial judge has broad discretion to elaborate remedial arrangements in response to the particular characteristics of the situation and parties before him.

Abram Chayes, "Foreword: Public Law Litigation and the Burger Court" (1982) 96:1 Harv L Rev 4 at 46. See also Abram Chayes, "The Role of the Judge in Public Law Litigation” (1976) 89:7 Harv L Rev 1281. 
Paul Gewirtz refers to the consideration of third party interests at the remedial stage as a process of "interest balancing" — the balancing of a claimed constitutional right against the interests of those parties affected by its enforcement. ${ }^{106}$ Importantly, he notes that not all third party costs will justify the attenuation of a remedy. Some "costs" reflect legitimate public values (to borrow the language of Fiss), while others do not:

Interest Balancers reject the view that a remedy’s costs may never justify limiting a remedy; they must still decide, however, which costs are allowed to limit a remedy, and how much limiting effect to give those costs. Even under Interest Balancing, some costs must be altogether unbalanceable - that is, they will not be permitted to weigh at all against remedial effectiveness. An example of a cost that should be unbalanceable in formulating a remedy for racial segregation is the "cost” of interfering with white racists' preferences to stay away from blacks because of their race. The objection to recognizing these costs is not simply that doing so would interfere with remedial effectiveness; if it were, all costs would be unbalanceable. Rather, the rejection of these costs is rooted in their relation to the right. The preferences of white racists are ignored not because such preferences are deemed offensive but because they involve an objection to the right itself. This clarifies the relevant distinction between different remedial costs: costs of the right, which are the distributive costs entailed by the end-state vision embodied in the right itself; and transitional costs of remedies for violations of the right, which are the costs imposed in order to move from the current situation to the end state. The former should always be unbalanceable; an objection to the right is not an interest that may count as an independent value to be weighed against furnishing a fully effective remedy. But objections to transitional remedial burdens should at least be balanceable. ${ }^{107}$

Gewirtz goes on to state that in order to justify attenuation of a remedy, a cost must not simply be legitimate, but must manifest to a particular degree: "If a cost is deemed balanceable, the remaining question is whether it is sufficiently weighty to justify limiting a remedy. In general terms, a particular remedy may be rejected under Interest Balancing if its costs ‘outweigh' or 'exceed' the remedial effectiveness it produces.”108

These observations resonate with the questions outlined at the beginning of this section. Suspended declarations of invalidity constitute an attenuation of a particular remedial outcome (an immediate vindication of the infringed right). The possible effects of an immediate declaration of invalidity - including forms of social harm or practical impediments to an optimal remedial disposition by the legislature — can be understood as costs that must be balanced against the interest in giving immediate effect to the right. The challenge lies in discerning which considerations or costs are legitimate, and once that

Paul Gewirtz, "Remedies and Resistance" (1983) 92:4 Yale LJ 585.

Ibid at 606-607 [footnotes omitted, emphasis in original]. This aspect of Gewirtz's argument is nuanced. Drawing from the context of racial desegregation in the United States, Gewirtz posits that each right (e.g. the right to equality) involves an ideal "end state" (e.g. desegregation) which the remedy is intended to achieve. However, resistance to either the right or to the remedy - including illegitimate resistance (such as a racist attack on the right) - might have to be accounted for in devising the remedy so that the remedy is made maximally efficient in pursuing its end state. This accounting is not intended to legitimate the resistance, but to enable the fulfillment of the right. For the purposes of this article, I have chosen to emphasize Gewirtz's more straightforward distinction between legitimate and illegitimate third party costs, and to characterize the former as being costs that reflect constitutional values. I feel justified in doing so because, fortunately, Canada has not suffered the trenchant social resistance to racial equality and other rights annunciated in the Charter that manifested in the United States' tortured experience with racial desegregation. 
threshold is met, whether they manifest to such a degree as to justify temporary suspension of the right.

In Part III, below, I propose an analytic method that meets these challenges. The method I propose is one that is already familiar to the courts because it is the same as that which they apply to evaluate the limitation of Charter rights. Although developed in the latter context, the method is calibrated to discern between constitutionally legitimate and illegitimate values that compete with rights and to balance the respective force of rights with those competing values. These qualities make it ideally suited to accommodating the distinct concerns that arise in the exercise of remedial discretion concerning suspended declarations.

\section{Proportionality AND the Limitation of Charter Rights}

Part II, above, described the evolution of suspended declarations of invalidity from their origin in the Manitoba Language Reference to the present day. It demonstrated that suspended declarations have grown away from their original foundations, which focused judicial analysis on the public interest, to become an instrument of remedial delegation to the legislature. As a consequence of this trend, the present usage of suspended declarations generates problems of inadequate reasoning, flawed institutional assumptions, and injury to Charter rights. A unifying feature of these consequences is that they involve the application of suspended declarations without just foundation. The result is intrinsically harmful to Canada's Constitution. As section 52 states, "the Constitution is the supreme law of Canada." The suppression of its dictates, even temporarily, for reasons that are inadequate, illconceived or simply unprincipled, is inimical to the Constitution's primary character. Moreover, the consequences to individual rights are real. The cases considered above concern individuals whose Charter rights have already been infringed by invalid legislative acts. It is unjust that they should suffer continued violation without clear and legitimate foundation.

The latter observation invites an analogy to the limitation of Charter rights. The effects of limiting a Charter right, and of temporarily extending the violation of a right by virtue of a suspended declaration, are equivalent in terms of the experiences of individuals suffering such violations; the only difference is that one state of affairs is permanent while the other is temporary. That distinction may have some significance when the harm suffered as a result of a violation is not particularly severe, but it rapidly loses significance as the violation becomes more substantial, as in cases like Demers, Rodriguez, Swain, and Charkaoui. Of course, Canada has a developed juridical approach to justifying the limitation of Charter rights in the form of the Oakes test, which applies section 1 of the Charter. Given the similarity in effect between rights limitations and suspended declarations of invalidity, it is surprising that the analytic approach governing the former has not been considered in terms of its relevance to the latter. That is the aim of this Part. Having suggested an equivalency in effect between suspended declarations and the limitation of Charter rights, I intend to demonstrate a commonality between the principles underpinning the section 1 limitations analysis and the principles originally animating suspended declarations. A foundation will thus be established for adapting a core feature of limitations analysis - the principle of proportionality — to respond to present problems in the usage of suspended declarations and 
to address the unique dilemmas that the courts face in the exercise of their remedial discretion.

\section{A. SECTION 1 OF THE CHARTER}

The wording of section 1 is deliberate, and its significance is underscored by briefly recalling the political process that led to the provision. Several alternate formulations of section 1 were considered and rejected during the development of the Charter. Janet Hiebert notes that during the earliest ruminations about an entrenched Bill of Rights, documented in a 1968 Ministry of Justice policy paper prepared under then Justice Minister Pierre Trudeau, a comprehensive limitations clause was not even contemplated. ${ }^{109}$ Rather, Trudeau preferred that a Bill contain no statement of limitations whatsoever, believing the judiciary could be trusted to develop responsible limits to rights. ${ }^{110}$

Ultimately, this view proved to be politically unpalatable, particularly among provincial governments reluctant to cede legislative supremacy over their areas of jurisdiction. ${ }^{111}$ Concern for the impact of entrenched rights on legislative power necessitated the inclusion of a limitations provision in the Charter. Thus, as federal-provincial negotiations for a Canadian Charter became more advanced during the early 1980s, the federal government proposed the following formulation of the limitations clause:

The Canadian Charter of Rights and Freedoms recognizes the following rights and freedoms subject only to such reasonable limits as are generally accepted in a free and democratic society with a parliamentary system of government. ${ }^{112}$

The tolerance for "generally accepted" limits on rights evident in this draft was a capitulation to the provincial governments' desire retain a broad ambit of legislative sovereignty. Had it been adopted, the imperatives of legislative sovereignty might have overridden the sanctity of individual rights enunciated in the Charter. The formulation came under attack, however, during hearings before the Special Joint Senate and House of Commons Committee on the Constitution, conducted over several months in 1980. The public character of these hearings helped reinforce the importance of constitutional rights by providing a forum for rightsseeking individuals and groups to share their lived experiences. ${ }^{113}$ Ultimately, public support for the Charter overcame provincial opposition. The final formulation of the limitations clause set a stringent standard: it required that limitations to the enumerated rights be "prescribed by law" and "demonstrably justified," placing the burden on the government to establish the necessity of limitations, and established the principles of a "free and democratic society" as a benchmark for justification. The unfettered freedom of legislatures to govern according to "generally accepted" standards of parliamentary sovereignty was expressly rejected. 
The adoption of the Charter brought Canada fully within what Lorraine Weinrib calls the "postwar" model of constitutional rights protection. ${ }^{114}$ Weinrib's model refers to the proliferation of entrenched human rights, both in state constitutions and in international instruments, which followed the end of the Second World War. By establishing human rights as bulwarks against the recurrence of totalitarian regimes, the postwar model transformed the relationship between individuals and the state. ${ }^{115}$ Just as importantly, however, it established a standard to be met by any law or state action that imposed limits on rights — a standard stated explicitly in section 1 as the values of a "free and democratic society."

Canada's Charter is often criticized for stating in its first provision that the subsequently enumerated rights are subject to limits. What is lost in this criticism is the recognition that section 1 is also an affirmation, not just of enumerated rights but of the values that underlie the entire Constitution. The requirement that limitations on rights accord with the principles of a free and democratic society affirms that rights and limitations flow from the same source - that both rights and limits on rights are to serve the same pre-eminent values, thus rendering Canada's constitutional structure coherent. As Weinrib writes:

Constitutional rights embody the bedrock principles of post-Second World War liberal democracy. Experience in the operation of rights-protecting instruments has demonstrated that it is these principles, not their crystallization as rights, which must be regarded as absolute. ... Limitation provisions in rightsprotecting instruments thus give legal expression to the common body of principles underlying the guarantees and the permitted basis for their limitation. They do not mark a boundary beyond which the exercise of plenary legislative authority reasserts itself, excluding the normative force of these principles. In operation, limitation provisions require demonstration by the state that any measure diminishing the enjoyment of the rights conforms to the principles, encapsulated in the formula for permitted limitation, that underlie the rights themselves. $^{116}$

In its first major treatment of section 1, the Supreme Court reinforced this view:

Inclusion of these words as the final standard of justification for limits on rights and freedoms refers the Court to the very purpose for which the Charter was originally entrenched in the Constitution: Canadian society is to be free and democratic. The Court must be guided by the values and principles essential to a free and democratic society which I believe embody, to name but a few, respect for the inherent dignity of the human person, commitment to social justice and equality, accommodation of a wide variety of beliefs, respect for cultural and group identity, and faith in social and political institutions which enhance the participation of individuals and groups in society. The underlying values and principles of a free and democratic society are the genesis of the rights and freedoms guaranteed by the Charter and the ultimate

See ibid at 121. See generally Lorraine Weinrib, "The Supreme Court of Canada in the Age of Rights: Constitutional Democracy, The Rule of Law and Fundamental Rights Under Canada's Constitution" (2001) 80:1 Can Bar Rev 699 [Weinrib, “Age of Rights”]; Lorraine E Weinrib, “The Postwar Paradigm and American Exceptionalism" in Sujit Choudhry, ed, The Migration of Constitutional Ideas (New York: Cambridge University Press, 2006) 84.

Weinrib, "Age of Rights," ibid at 704: "Rights guarantees have emerged as the favoured instrument by which to protect the basic structure of constitutional democracy. These guarantees establish new institutional roles that have the effect of reconstructing the relationship between the state and the individual as citizen and right holder." 
standard against which a limit on a right or freedom must be shown, despite its effect, to be reasonable and demonstrably justified. ${ }^{117}$

Under the postwar model, sovereignty resides not in institutions of political power but in individuals endowed with rights that affirm their preeminent freedom and dignity. Legislatures, of course, retain a wide ambit of power, but any limitations they impose upon Charter rights must be justified by the underlying, sovereign interest of the people. Moreover, the state itself owes a duty to recognize and protect rights, including protection through the instrument of judicial review. ${ }^{118}$ As Weinrib observes: "The postwar model does not simply negate state power. It delineates the institutional mechanisms that transform a system of legislative sovereignty into a system of constitutional supremacy.”119

When one considers the significant restrictions erected against unjust limitations on Charter rights under Canada's constitutional model, the offence of permitting the temporary suspension of such rights without sound justification becomes plain. Moreover, the postwar model places the Schachter categories in a new light. Clearly, those categories serve to define instances in which the harm inflicted by an immediate declaration of invalidity outweighs its beneficial effect. The content of the categories - injury to the rule of law, public harm, and the deprivation of benefits to deserving persons - clearly align with the values of a free and democratic society. Chief Justice Lamer also cautioned that the categories were not intended to constitute a closed list. Accordingly, there is good reason to look past the Schachter categories and to focus on their underlying preoccupation: the protection of the public interest, a value clearly aligning with the commitments of a free and democratic society. It thus makes sense that Chief Justice Lamer would warn against referring to separation of powers considerations in issuing a suspended declaration: it is the interests of the public that suspended declarations are intended to service, not the interests of the legislature. The balancing of such a value against the imperative of giving immediate effect to constitutional rights is exactly the type of analysis commanded by the postwar model and facilitated by the method of proportionality analysis discussed in the next section.

\section{B. The OAKes Test and Proportionality}

Part III.A, above, recounted Canada's commitment to a postwar model of constitutional rights protection. As this nomenclature implies, Canada is not alone in combining enumerated, constitutionally entrenched rights with a provision that requires limits be reconcilable with the principles of a free and democratic society. As Grégoire Webber observes, limitations clauses in the style of section 1 "are familiar to students of international instruments, including the Universal Declaration of Human Rights and the European Convention on Human Rights; constitutional charters of rights, including the Canadian Charter of Rights and Freedoms and the South African Bill of Rights; and statutory bills of rights, including the British Human Rights Act and the New Zealand Bill of Rights." ${ }^{120}$

Oakes, supra note 10 at para 64 [emphasis added].

See Weinrib's description of the three tenets of constitutional government in Weinrib, "Age of Rights," supra note 114 at 701.

Weinrib, "Paradigm Lost," supra note 113 at 131.

Grégoire CN Webber, The Negotiable Constitution: On the Limitation of Rights (New York: Cambridge University Press, 2009) at 2 [footnotes omitted]. 
Similarly, the method of enforcing a limitations provision — proportionality analysis — is a matter of internationally widespread judicial practice. Alec Stone Sweet and Jud Mathews observe:

From German origins, [proportionality analysis (PA)] has spread across Europe, including into the postCommunist states in Central and Eastern Europe, and into Israel. In has been absorbed into Commonwealth systems ... and it is presently making inroads into Central and South America. By the end of the 1990s, virtually every effective system of constitutional justice in the world, with the partial exception of the United States, had embraced the main tenets of PA. ${ }^{121}$

In Canadian jurisprudence, those tenets were adopted in the Supreme Court's landmark decision in $R v$ Oakes, establishing the so-called Oakes test.

The Oakes test places the onus on government to demonstrate the legitimacy of a rightslimiting measure. It comprises two components. ${ }^{122}$ The first component concerns legality, the requirement that limitations on rights be "prescribed by law." This demands that limitations be effected through the official, transparent law-making institutions of the state. ${ }^{123}$ The second component concerns legitimacy, the requirement that limitations reflect the values of a free and democratic society. It is during the legitimacy stage that proportionality analysis is brought to bear.

The Supreme Court has set out the stages of proportionality analysis as follows:

(1) Is the legislative objective which the measures limiting an individual's rights or freedoms are designed to serve sufficiently pressing and substantial to justify the limitation of those rights or freedoms?

(2) Are the measures chosen to serve that objective proportional to it, that is:
a. Are the measures rationally connected to the objective?
b. Do the measures impair as little as possible the right and freedom in question; and
c. Are the effects of the measures proportional to the objective identified above? ${ }^{124}$

Under the first stage of proportionality analysis, ${ }^{125}$ a measure limiting a right must be shown to have a valid object: a pressing and substantial goal that warrants interference with the Charter. The benchmark for justification is that the goal accords with the values of a free and

Alec Stone Sweet \& Jud Mathews, “Proportionality, Balancing and Global Constitutionalism” (2008) 47:1 Colum J Transnat'l L 72 at 74.

See discussion in Weinrib, “Paradigm Lost,” supra note 113 at 127.

Ibid.

Summarized in Schachter, supra note 4 at 703.

In Canadian jurisprudence, the "pressing and substantial objective" criteria is often stated as a predicate to the question of whether a law is "proportionate," referring to the subsequent stages of the Oakes test. See e.g. Alberta v Hutterian Brethren of Wilson Colony, 2009 SCC 37, [2009] 2 SCR 567 at para 47 [Hutterian Brethren]. It is clear, however, that the pressing and substantial branch of the Oakes test forms part of proportionality analysis as it is conceived in the international jurisprudence and doctrine of which Canadian law is a part. For this reason, I include the first branch of Oakes in my description of proportionality analysis. Indeed, the first branch serves an essential gatekeeper function in ensuring that the purpose of an impugned provision reconciles with the principles of a free and democratic society — the guiding commitment of the postwar model. 
democratic society. The goal of protecting public safety, for example, might justify the use of a particular criminal law measure despite impinging on Charter rights, whereas the goal of promoting racial differentiation, being inimical to the values of freedom and democracy, would not.

A valid object having been shown, the second component of the proportionality test is engaged - that the measure incorporate valid means. The means must be tailored "rationally" to fit the objective, meaning they should actually further the objective. This does not require that the government give factual proof that its means are effective in attaining their purpose, but that a reasonable, logical connection lie between the means and the purpose. As the Supreme Court recently stated in Hutterian Brethren, "[t]he rational connection requirement is aimed at preventing limits being imposed on rights arbitrarily."126

Moreover, the means must impair the right to only the minimum extent necessary to meet their goal. A pressing and substantial objective pursued through overbroad measures will not pass this third stage of the test which, like the rational objective standard, serves as a barrier against arbitrariness. The Supreme Court's approach to the minimal impairment standard was most clearly stated in RJR-MacDonald Inc v Canada (AG):

\footnotetext{
The impairment must be "minimal”, that is, the law must be carefully tailored so that rights are impaired no more than necessary. The tailoring process seldom admits of perfection and the courts must accord some leeway to the legislator. If the law falls within a range of reasonable alternatives, the courts will not find it overbroad merely because they can conceive of an alternative which might better tailor objective to infringement. ... On the other hand, if the government fails to explain why a significantly less intrusive and equally effective measure was not chosen, the law may fail. ${ }^{127}$
}

The latter portion of the Court's statement is key: while minimal impairment does not demand a standard of perfection, it does require that the government answer, in a reasonable and cogent manner, why it did not pursue other alternatives that may have been less impairing of rights. Recent Supreme Court jurisprudence might be criticized for displaying excessive deference to government choices under this branch of the test, requiring simply that such choices be "reasonable" without specifically referring to the principles of a free and democratic society. In order to reconcile with the postwar model, the principles of a free and democratic society should ground the government's justification of its choice of impairing alternative, just as it does in the case of demonstrating a pressing and substantial objective. ${ }^{128}$

Finally, under the last stage of proportionality, the means (or more specifically, the effect of those means on the right) must be proportionate to the importance of the objective they serve. This final step ("proportionality stricto sensu") does not simply balance a constitutional right against a legitimate, competing purpose; it balances the specific limitation

\footnotetext{
$126 \quad$ Ibid at para 48.

127 [1995] 3 SCR 199 at para 160 [RJR-MacDonald].

128 For a compelling critique of the Supreme Court's tendency towards deference under the Oakes test, see Weinrib, "Paradigm Lost,” supra note 113. Even in the excerpt from RJR-MacDonald quoted above, it is questionable why the Court holds that failure by the government to reasonably explain its neglect of a less impairing alternative "may" result in an impugned measure being struck down. Why not "must"? Has the Court not already granted the legislature enough leeway in recognizing that it cannot expect perfection but only demonstration of "reasonable" deliberation among options?
} 
of the right against the specific furtherance of the purpose than can realistically be accomplished by a measure. ${ }^{129}$ Some have suggested that the final stage of proportionality analysis is redundant — that it is satisfied already by asking whether a measure has a "pressing and substantial objective" such as to warrant limitation of a right. ${ }^{130}$ The Supreme Court answered this criticism in Hutterian Brethren by noting that the final stage of proportionality analysis focuses on a measure's effect, not its purpose:

\footnotetext{
It may be questioned how a law which has passed the rigours of the first three stages of the proportionality analysis — pressing goal, rational connection, and minimum impairment — could fail at the final inquiry of proportionality of effects. The answer lies in the fact that the first three stages of Oakes are anchored in an assessment of the law's purpose. Only the fourth branch takes full account of the "severity of the deletrious effects of a measure on individuals or groups.”131
}

It is for this reason that Aharon Barak, former President of the Israeli Supreme Court, refers to proportionality stricto sensu as "the very heart of proportionality," ${ }^{32}$ noting "[i]t recognizes the fact that not all means with a rational connection to the objective that are the least drastic ones possible do, in fact, justify the realization of the objective. The ends do not justify all means. There is a moral limit which democracy cannot surpass."133

Proportionality analysis is not without its critics. Webber challenges it on two fronts, arguing that proportionality suffers from incommensurability ${ }^{134}$ and that it has the effect of "[d]econstitutionalizing rights." 135 The problem of incommensurability arises because, in his view, proportionality does not measure rights and limits according to a common benchmark; that is, when a court considers the importance and effect of a right and purports to balance this against the importance and effect of a limiting measure, its "balancing" is illusory, because the court has not identified a common unit of measurement that can be applied to the competing ideas. Moreover, in the absence of a common unit of measurement, proportionality reduces rights adjudication to a technical exercise, depriving it of substantive moral content: "The structure of proportionality analysis itself does not purport (at least explicitly) to struggle with the moral correctness, goodness or rightness of a claim but only with its technical weight, cost or benefit. The principle of proportionality — being formal or empty — itself makes no claim to correctness in any morally significant way."136

This assertion is closely related to Webber's second line of critique, that proportionality “deconstitutionalizes” rights. He writes:

See Aharon Barak, “Proportional Effect: The Israeli Experience” (2007) 57:2 UTLJ 369 at 374, 380. See also Justice Abella's dissenting reasons in Hutterian Brethren, supra note 125 at para 152, where she helpfully explains that the final stage of proportionality centres on two questions: "How deeply is the right infringed?" and "What is the degree to which the impugned limitation will advance its underlying objective?"

130 See Peter W Hogg, Constitutional Law of Canada, 5th ed Supp, vol 2 (Toronto: Thomson Reuters Canada, 2007) at 38-44.

Hutterian Brethren, supra note 125 at para 76, citing Barak, supra note 129 at 374.

Barak, ibid at 380.

Ibid.

Webber, supra note 120 at $89 \mathrm{ff}$.

Ibid at $100 \mathrm{ff}$.

Ibid at 90 [emphasis in original]. 
Whatever the constitution does, proportionality can undo. Proportionality and balancing effectively translate all rights into reasons that trigger a first-order assessment as to whether the current state of affairs is best overall. Any stipulated rights fail to serve as second-order reasons for acting or not acting. Instead, they collapse into a general right to proportionality evaluations. ${ }^{137}$

In other words, proportionality translates rights into a technical balancing exercise rather than affirming their distinct, independent moral character — it reduces them to a general "right to proportionality.” In a similar vein, Brian Slattery has criticized the Oakes test for imposing a "monistic" approach to rights limitation which, in his view, diminishes the individual distinctness of Charter rights. He argues instead for a "pluralistic approach" to the limitation of rights, under which "the constitutional test is part and parcel of each particular Charter guarantee and employs detailed criteria that reflects its distinctive nature, purposes, and genesis, as well as the specific subject matter at issue.”138 Both Webber and Slattery share a common concern that proportionality analysis inhibits the potential for rights to become more clearly defined through time (through legislative and judicial processes) in a manner that meaningfully reflects their distinct, individual character; by starting with a broad, encompassing view of rights and then imposing a singular method to test the legitimacy of "infringements," proportionality denies the possibility for the boundaries of rights to be established independently, in reference to their own moral content.

These criticisms have some basis. There is certainly a tendency among prominent advocates of proportionality to treat the latter as possessing its own normative content equivalent or even preeminent to the normative content of the rights and interests it strives to balance. Robert Alexy, for example, argues that rights (and other public law principles) are "optimization requirements," meaning they "require that something be realized to the greatest extent possible given the legal and factual possibilities." ${ }^{139}$ Because rights do not have the determinacy of rules, competitions between them (and between them and other principles) cannot be resolved through invalidation, exceptions, or by giving primacy to one over another; ${ }^{140}$ rather, they must be resolved by balancing the respective weight of the competing optimization requirements in a given context. Stone Sweet and Mathews explain:

\footnotetext{
If rights are "optimization requirements," binding on all public (and in some cases, private) authorities, then rights adjudication (and therefore lawmaking more generally) reduces to balancing. Further, the purpose of balancing must be both to resolve alleged conflicts between principles, and to aid all of the organs of the state in their task of optimizing rights and other countervailing principles. ${ }^{141}$
}

This, of course, feeds directly into Webber's critique that proportionality emasculates rights by reducing them simply to a "right to proportionality.” David Beatty similarly fuels this critique when he proclaims:

Ibid at 100 .

Brian Slattery, “The Pluralism of the Charter: Revisiting the Oakes Test” in Luc B Tremblay \& Grégoire CN Webber, The Limitation of Charter Rights: Critical Essays on R. v. Oakes (Montreal: Éditions Thémis, 2009) 13 at 19-20.

Robert Alexy, A Theory of Constitutional Rights (New York: Oxford University Press, 2002) at 47. See also Robert Alexy, “Balancing, Constitutional Review, and Representation” (2005) 3:4 Int'l J Const L 572.

See Stone Sweet and Mathews' helpful explanation of Alexy's theory in supra note 121 at 94 . Ibid [emphasis in original]. 
It is all and only about proportionality. Because all laws limit liberty, and/or discriminate among people in some way, and because, as the jurisprudence shows, proportionality is what basic rights of liberty, equality, and fraternity actually guarantee, it sets the standard that every law, every act of government, must meet.

When rights are factored into an analysis organized around the principle of proportionality, they have no special force as trumps. They are really just rhetorical flourish. ${ }^{142}$

It is no surprise that such a provocative assertion has elicited strong rebuke by critics such as Webber.

Ultimately, however, these critics take too narrow a view of proportionality. It is true that, in the abstract, proportionality is simply a "doctrinal construction"143 — an analytic device conceived by judges to enable a particular adjudicative task. But it is important is to consider how that analytic device can assist the underlying commitments of the postwar model of rights protection. Under the postwar model, a rights limitation cannot cross even the first threshold of proportionality unless it is shown to advance the principles of a free and democratic society. Similarly, at the stage of minimal impairment, the choice of a limiting measure must be defended in reference to freedom and democracy. Finally, as Justice Barak points out, proportionality stricto sensu ensures that well-intended means cannot justify all ends — that there are some limits on rights which simply cannot be justified, again evoking the moral limits of a free and democratic society. Webber's critique of incommensurability is thus resolved by recognizing that rights and their limits do deal in the same currency indeed, it is the very point of the postwar model to ensure that rights and limits are justified and measured according to the common moral benchmarks of freedom and democracy. Similarly, these benchmarks infuse proportionality analysis with a moral content, one derived not from proportionality itself but from its specific application in reference to the values of freedom and democracy. Proportionality thus does not emasculate rights; it supplements them — it ensures that in addition to the unique content of the rights themselves, their limits be established in reference to underlying moral commitments which sustain the rights themselves. To the extent that there is a "right to proportionality" under the postwar model, it only strengthens the integrity of the enumerated rights and their distinct, individual content.

Having explained proportionality as an analytic method and its significance in the postwar model of rights protection, it is possible to demonstrate how proportionality would assist judges in navigating the issues that surround suspended declarations of invalidity.

\section{Proportionality ANALYSIS AND SUSPENDED DECLARATIONS OF INVALIDITY}

I propose that judges utilize proportionality analysis to determine the propriety of issuing a suspended declaration of invalidity. This would require that, prior to issuing a suspended 
declaration, judges ask themselves a series of questions duplicating the stages of the Oakes test, namely:

- Would issuance of a suspended declaration of invalidity serve a pressing and substantial purpose?

- Is there a rational connection between the purpose and a suspended declaration?

- What impact on Charter rights will arise from the issuance of a suspended declaration, and is a suspended declaration the most minimally impairing measure that can be employed to achieve its objective?

- Will the specific benefits achieved by the suspended declaration outweigh any adversity it inflicts on Charter rights?

Having asked themselves these questions, judges should state reasons of sufficient clarity to demonstrate that, when a suspended declaration is issued, the core elements of proportionality have been met. Moreover, judges should be responsible for initiating proportionality analysis themselves. ${ }^{144}$ While submissions from the parties to a constitutional dispute may be helpful, it is ultimately the court that is responsible for the impact a suspended declaration will have on individual rights and on other matters in the public interest. Accordingly, the onus should rest with judges to justify this choice of remedial instrument in reference to the principles of a free and democratic society. Proportionality analysis would provide an ideal method for doing so and for meeting the unique dilemmas of remedial discretion.

The first analytic step — demonstrating a pressing and substantial purpose - would require a court to state the possible consequences of an immediate declaration of invalidity, and to explain why those consequences should be avoided. These may be that an immediate declaration of invalidity will inflict a harm of the type contemplated in the Schachter categories. Or perhaps immediate invalidation will inflict a harm unforeseen by Schachter, such as prejudice to Aboriginal rights that are incidentally affected by the Charter. Or it may be that immediate invalidation will erect barriers to the legislature crafting an optimal response to the court's declaration, and thus prejudice the public interest in a sound, longterm remedial solution. The latter justification is the most nuanced, as it will require the court to explain why legislative discretion is hindered by an immediate declaration of invalidity - that is, why the legislature's ordinary power to legislate in the face of an immediate declaration is inadequate.

This issue would be well addressed by the next stage of proportionality. By asking if there is a rational connection between the suspended declaration and its purpose, the court would would have an unavoidable negative impact on the exercise of Charter rights and freedoms, then the burden of demonstration should fall on the government seeking the suspended declaration, as is the case with other section 1 limits.” Supra note 26 at 283. In my view, placing the onus on government would not adequately address those instances in which the courts are impelled to issue a suspended declaration based on their own assessment of the public interest. 
be forced to confront the possibility that suspension does nothing (or very little) to enhance the breadth of remedial options available to the legislature in reply. Accordingly, it will not be sufficient for the court to speak in abstractions or to offer mere propositions about its role vis-à-vis the legislature. The court will be required to explain why it cannot provide an adequate, immediate remedy; why the legislature is better suited to this task; and why the legislature must be enabled through the specific instrument of a suspended declaration.

The first two stages of proportionality analysis alone would go a considerable distance toward solving the problems evident in the current use of suspended declarations. By requiring the court to speak in the language of a "pressing and substantial objective," the first stage reinforces the underlying focus of the Manitoba Language Reference, Swain, and Schachter on the public interest. It would immediately solve the problem of inadequate reasoning evident in cases such as Figueroa, Fraser, and Nguyen, where the courts simply offered institutional propositions without attempting to convey specific concerns of a pressing and substantial character that justified the suspension of an immediate remedy. The rational connection requirement would challenge the court to think deeply about whether legislative discretion is truly hindered by an immediate declaration of invalidity and whether such obstruction is sufficient to justify a suspended declaration based on the public interest in an ideal, long-term remedy. This might solve the problem of flawed institutional assumptions evident in cases such as Corbiere and Charkaoui.

The third stage in proportionality analysis, minimal impairment, would require the court to expressly recognize that suspended declarations inflict injury to constitutional rights to define the nature of that injury and to consider, in light of it, whether other alternatives exist to fulfill the pressing and substantial objective defined at the first stage. Should such alternatives not exist, the "minimal impairment" criteria would nevertheless impel the court to consider a host of measures that might diminish the harshness of a suspended declaration, for example: imposing a tight deadline on the suspended declaration; imposing conditions upon the suspended declaration; retaining supervisory jurisdiction throughout the period of suspension; or employing section 24(1) remedies in combination with the suspended declaration. A principled foundation would thus be established to move past dogmatic adherence to the so-called "rule in Schachter" which limits the combination of declarative and structural remedies, and to provide meaningful interim relief that insulates individuals against the negative effects of suspended declarations. Thus the applicants in cases such as Demers and Charkaoui would receive a remedy more consonant with their constitutional rights.

The final step of proportionality analysis would require the court to balance the specific benefit secured by the suspended declaration against the specific injury it inflicts to constitutional rights. More than simply reiterating the analytic focus of the first stage, proportionality stricto sensu demands that the court's analysis be exact: it is not enough that suspension serve a generally laudable purpose; the court must articulate a real, specific objective that displaces the real, anticipated consequences of suspension for constitutional rights. The final stage of proportionality analysis secures this requirement.

In sum, proportionality would provide a flexible, nuanced analytic lens through which to weigh the considerations involved in the issuance of a suspended declaration. It would allow 
departure from the categories of Schachter but not departure from the constitutional principle that underlies them. Indeed, proportionality would serve to reconcile suspended declarations with the postwar commitments of Canada's constitution. The result would be not just beneficial in theory, it would enhance the practical enforcement of individual constitutional rights and ensure that their temporary suspension is only justified by imperatives in the public interest. $^{145}$

\section{CONCLUSION}

I have proposed that proportionality be adopted to provide an analytic framework governing the use of suspended declarations of invalidity in Canadian constitutional law. The features of that framework are familiar to Canada's courts: they derive from the courts' existing approach to the limitation of Charter rights, and more importantly from the principles of Canadian constitutionalism that this approach reflects and affirms. A central feature of Canada's Constitution is its commitment to human dignity in the form of Charter rights. The limitation of those rights requires justification by objectives that possess their own legitimate constitutional force. Their temporary suspension should require no less a justification.

The early authorities on suspended declarations in Canada, notably the Manitoba Language Reference, Swain, and Schachter, provided an analytic foundation that accorded with the principles of Canadian constitutionalism. Unfortunately, as subsequent cases departed from the "categories" established by these early decisions, the more important principles underlying the categories were lost. Rather than focusing on the public interest, the contemporary analytic approach to suspended declarations focuses on the remand of remedial authority to the legislature, a justification foreign to the original purpose of suspended declarations and at odds with the precepts of Canada's constitutional model. While occasionally aligning with the public interest, the use of suspended declarations to delegate remedial tasks to the legislatures has had predominantly harmful effects. It has produced a problem of analytic incoherency, exacerbated flawed institutional assumptions that impose undue costs on Charter claimants, and caused unnecessary injury to Charter rights, particularly where the denial of interim remedies under section 24(1) of the Charter is concerned. The effects suffered by individual citizens as a consequence of these problems are equivalent to the outright limitation of their Charter rights, yet they do not benefit from the rigor of the section 1 limitations analysis when suspended declarations are judicially imposed.

An improved analytic framework for suspended declarations must address the reasons for their expanded usage while remaining true to constitutional principle. Proportionality provides such a framework. It embraces the institutional considerations that weigh on the

145 I have argued elsewhere that certain decisions of South Africa's Constitutional Court showcase the core features of proportionality in issuing suspended declarations of invalidity, and may provide a useful reference for Canada's courts. See an earlier version of this article completed as my LLM thesis, Grant Russell Hoole, Proportionality as a Remedial Principle: A Framework for Suspended Declarations of Invalidity in Canadian Constitutional Law (LLM Thesis, University of the Toronto 2010) at 79-91 [unpublished]. The South African case law is intriguing because South Africa's Constitution makes express provision for suspended declarations. See Constitution of the Republic of South Africa, 1996, No 108 of 1996, s 172. 
courts' exercise of remedial discretion without undermining the principles that both empower and command courts to enforce rights; it focuses judicial analysis on the public interest, requiring that the reason for a suspended declaration be stated in these terms, and balanced against the imperative of giving immediate vindication to constitutional rights. In so doing, proportionality analysis reconciles suspended declarations with the principles of a free and democratic society. As such, I argue that in determining whether or not to issue a suspended declaration, a court should ask:

- Would issuance of a suspended declaration of invalidity serve a pressing and substantial purpose?

- Is there a rational connection between the purpose and a suspended declaration?

- What impact on Charter rights will arise from the issuance of a suspended declaration, and is a suspended declaration the most minimally impairing measure that can be employed to achieve its objective?

- Will the specific benefits achieved by the suspended declaration outweigh any adversity it inflicts on Charter rights?

The courts do not face a steep learning curve in adopting proportionality analysis to govern suspended declarations. They can draw from their own rich experience applying section 1 to the limitation of Charter rights.

The analytic model I propose will not result in the removal of suspended declarations from Canadian constitutional jurisprudence, nor is it intended to. It will, by necessity, lead to a more limited usage of suspended declarations and provoke the courts to issue bolder remedies in the form of increased immediate declarations of invalidity and creative new evocations of section 24(1) of the Charter. That is entirely appropriate in a stable constitutional democracy such as Canada, possessing both a central commitment to rights and a sophisticated institutional apparatus to enable legislative reply to judicial rulings. 